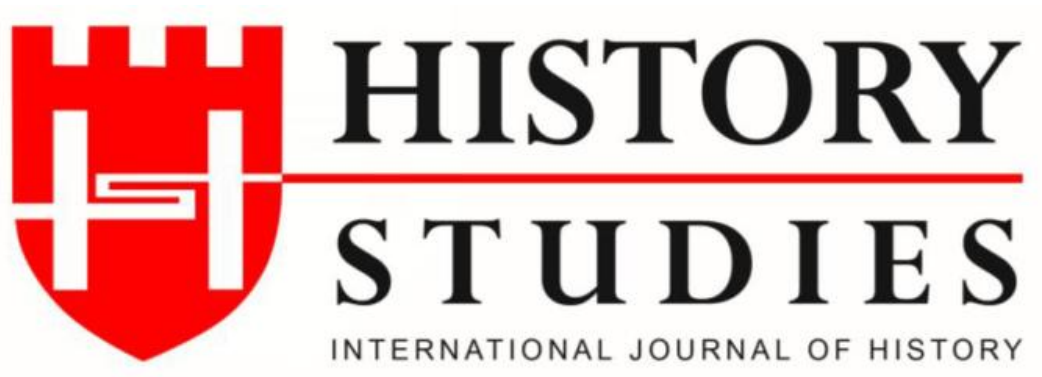

ISSN: 13094173 (Online) 1309 - 4688 (Print)

Volume 12 Issue 4, August 2020

DOI Number: 10.9737/hist.2020.905

Araştırma Makalesi

Makalenin Geliş Tarihi: 07.06.2020 Kabul Tarihi: 17.07.2020

Atıf Künyesi: Hacer Kara - İlker Mimiroğlu, "Koyunoğlu Şehir Müze ve Kütüphanesinde

Bulunan Osmanlı Dönemi Kılıçları", History Studies, 12/4, Ağustos 2020, s. 1915-1953.

\title{
Koyunoğlu Şehir Müze ve Kütüphanesinde Bulunan Osmanlı Dönemi Kilıçları*
}

\author{
The Ottoman Period Swords in the Koyunoğlu City Museum and Library
}

\author{
Dr. Hacer Kara - İlker Mimiroğlu \\ ORCID No: 0000-0002-0039-7947 / 0000-0003-0007-5355 \\ Necmettin Erbakan Üniversitesi
}

Öz: Tarih öncesi çağlardan itibaren insanoğlunun en çok kullandığı kesici silahlardan birisi olan kılıç, dönem ve kültürlere bağlı olarak biçim, teknik ve süsleme özellikleri bakımından farklılıklar göstermiştir. Türk kültürü ve sanatında da son derece önemli bir yer teşkil eden kılıçlar, önemli bir saldırı ve savunma aracı olmasının yanında, törenlerinde vazgeçilmez bir unsuru olarak kullanılmıştır. Ahmet Rasih İzzet Koyunoğlu'nun 1913 yılından itibaren biriktirdiği çok değerli eserleri Konya Belediyesi'ne bağışlaması ve bu eserler için müstakil bir binanın yapılmasıyla 1984 yılında hizmete açılan ve Türkiye'de belediyeler tarafından kurulmuş ilk özel müze olan Koyunoğlu Şehir Müze ve Kütüphanesi, Anadolu Medeniyetlerine ait arkeolojik buluntular, etnografik eserler, halılar, kilimler, mutfak eşyaları, silahlar, sikkeler, tespihler, yazma eserler ve farklı türlerde basılı kitaplardan oluşan oldukça zengin bir koleksiyona sahiptir. Müzenin koleksiyonunda bulunan silahları ateşli ve ateşsiz silahlar olarak sınıflandırmak mümkündür. Ateşsiz silahlar içinde kılıçlar, hançerler, teberler, gürzler, baltalar ve kamalar sayılabilir. Bu çalışma kapsamında bahsi geçen silahlardan yalnızca Osmanlı dönemine ait olan kılıçlar incelenmiştir. $\mathrm{Bu}$ doğrultuda müzede bulunan ve henüz yayınlarda yer almayan 26 adet kılıç ve bir adet kılıç sapı konumuz kapsamında ayrıntılı bir biçimde tanıtılmıştır. Malzeme, teknik, form ve süsleme açısından ayrıntılı olarak değerlendirilen bu eserler, farklı müze ve özel koleksiyonlardaki benzer örneklerle kıyaslanmıştır. İncelediğimiz silahlarda malzeme olarak namlu kısımlarında çelik ve demir, kabza kısımlarında kemik, pirinç ve ahşap, kınlarda ise ahşap üzerine deri kaplama ve nikelaj kullanıldı̆̆ edilmiştir. Eserlerin süslemelerinin zemin oyma, kabartma ve kazıma tekniklerinde yapıldığı görülmektedir. Süsleme kompozisyonları bakımından geometrik, figürlü ve bitkisel motiflerin yanı sıra yazıya da yer verilmiştir. Geometrik motifler içinde zikzaklar, birbirini farklı açılarda kesen ışınsal çizgiler, ay-yıldız, daire formları ve " $C$ " kıvrımları sayılabilir. Bitkisel süslemede barok-rokoko tarzı kıvrım dallar, altı yapraklı çiçekler, yapraklar ve selvi motifleri görülmektedir. Eserlerin bazılarının kabzalarında aslan, bazılarının namlularında insan ve kartal ve bir eserin kınında yılan-ejder figürü işlenmiştir. Kılıçların bir kısmında Arap ve Latin alfabesiyle yazılmış yazılar görülmektedir. Kazıma ve kakma tekniğinde yazılan bu yazıların bir kısmında tarih belirtilmiştir. Ele alınan örneklerin üzerlerinde bulunan tarihlerden ve bezeme kompozisyonlarından yola çıkılarak tamamının geç dönem Osmanlı eserleri oldukları tespit edilmiştir. Yaptığımız bu 
çalışmayla, Koyunoğlu Şehir Müze ve Kütüphanesinde incelediğimiz kılıçların Osmanlı dönemi silahları içindeki sanatsal ve tarihsel yeri belirlenmeye çalışılmıştır.

Anahtar Kelimeler: Koyunoğlu Şehir Müze ve Kütüphanesi, Osmanlı Dönemi, Silah, Kılıç

Abstract: The sword, which is one of the cutting weapons used by human beings since prehistoric times, differs in terms of shape, technique and decoration depending on the period and cultures. Swords, which have an extremely important place in Turkish culture and art, have been used as an essential element in the ceremonies as well as being an important attack and defense tool. Ahmet Rasih İzzet Koyunoğlu donated the valuable works he collected since 1913 to Konya Municipality. A building was constructed for exhibiting of these works in 1984. This building was the first private museum founded by municipalities in Turkey is the City Museum and Library. It has a very rich collection belonging to Anatolian Civilizations that includes archaeological finds, ethnographic works, carpets, rugs, kitchenware, weapons, coins, rosaries, manuscripts and printed books of different types. It is possible to classify the weapons in the collection of the museum as firearm and non-firearm weapons. Among the firearms, swords, daggers, halberds, maces, axes and wedges can be counted. Within the scope of this study, only swords belonging to the Ottoman period were examined. 26 swords and one sword handle in the museum, which have not been published yet, were introduced in detail within the scope of our subject. These works, which are evaluated in detail in terms of material, technique, form and decoration, were compared with similar examples in different museums and private collections. Steel and iron were used in the gun barrel parts as materials. Bone, brass and wood were used in the handle parts. İn the scabbard parts, leather coating and nickelplating were used on wood. It is seen that the decorations on the works are made in the ground carving, embossing and scraping techniques. In addition to geometrical, figured and floral motifs in terms of ornamental compositions, the text is also included. Zigzags, radial lines that cross each other at different angles, moon-star, circle forms and " $\mathrm{C}$ " curves can be counted in geometric motifs. Vegetable decoration shows baroque-rococo style folded branches, six-leaf flowers, leaves and cypress motifs. In the handle of some of the works, the figure of a lion, in some of the gun barrels of man and eagle, and, a snakedragon figure in the scabbard of a work were engraved. Writings written in Arabic and Latin alphabet can be seen on some of the swords. In some of these writings written in the technique of scraping and painting, history is indicated. Based on the dates and decoration compositions on the examples examined, it was determined that all of them were late Ottoman works. With this study, we have tried to determine the artistic and historical place of the swords that we examined in the Koyunoğlu City Museum and Library among Ottoman weapons.

Keywords: Koyunoğlu City Museum and Library, Ottoman Period, Gun, Sword

\section{Giriş}

Araştırmamızın konusu "Koyunoğlu Şehir Müze ve Kütüphanesinde Bulunan Osmanlı Dönemi Kılıçları" olarak belirlenmiştir. Müzede 13-19. yüzyıllar arasına tarihlendirilebilen çok farklı türde ateşsiz ve ateşli silahlar mevcuttur. Konumuz kapsamında bir kısmı müzenin teşhirinde, bir kısmı ise depolarında bulunan bu silahlar içinden 26 adet kılıç ve bir adet kılıç sapı incelenmiştir. Tespit edilen Osmanlı dönemine ait bu örneklerin fotoğrafları çekilmiş, çizimleri yapılmış ve üzerlerinde metinleri bulunanlar okunmuş ${ }^{1}$, her bir eser malzeme, teknik,

* Bu çalışma, 28-29 Şubat 2020 tarihlerinde Konya'da düzenlenen 3. Uluslararası Asya Modern Bilimler Kongresi'nde sunulmuştur.

${ }^{1}$ Müzede yaptığımız çalışmalar sırasında her türlü kolaylığı sağlayan ve yardımlarını esirgemeyen Müze Müdürü Hasan Boydak, Sanat Tarihçisi Muhammet Yaşar Çuhadar, Arkeolog Gülsüm Akcan ve tüm müze çalışanlarına 
form ve süsleme açısından ayrıntılı bir biçimde anlatılmıştır. Bu konuyu seçmemizdeki en önemli amaç ise incelemelerimiz sırasında "Yatağan", "Pala", "Süvari (Sabre) K1lıcı", "Düz Kılıç", "Ucu Hafif Eğri Kılıç", "Tören Kılıcı" ve "Kısa Kılıç" olarak sınıflandırdığımız bu kılıçların ve bir adet kılıç sapının Osmanlı dönemi silahları içindeki yeri ve önemini vurgulamak ve bu eserlerin gün yüzüne çıkarılmasını sağlamaktır. Yaptığımız bu çalışmada kılıçlar ilk olarak türlerine göre, her bir tür ise kendi içinde kronolojik olarak sıralanmıştır.

Konumuza ilişkin literatür taranırken silahlar üzerine genel bilgiler veren çalışmalar ve bazı müzelerin envanterinde kayıtlı bulunan silahlara dair tezler ve çeşitli yayınlara rastlanmıştır. Ancak Koyunoğlu Müzesindeki Osmanlı kılıçları üzerine yapılmış bir çalışma bulunmadığı tespit edilmiştir.

Barut icat edilip, ateşli silahlar ortaya çıkıncaya kadar savaşlarda ateşsiz silahlar kullanılmış ve sonrasında da bu silahlar birkaç asır boyunca ateşli silahlarla birlikte kullanılmaya devam etmiştir. $^{2}$ Ateşsiz silahlar içinde kesici silahlar her daim önemini korumuştur. Kılıçlar bunların başında gelmektedir. "Uzun, düz veya eğri, ucu sivri, bir veya her iki yüzü keskin, kın içinde bele takılan, çelikten silah" ${ }^{3}$ olarak tanımlanan kılıç, zaman zaman kılınç ${ }^{4}$, kilic, kilis ve kiliş ${ }^{5}$ şeklinde de söylenegelmiştir. Mihrican Çolak yaptığı çalışmada; Türk kültüründe önemli bir yere sahip olan k1lıcın atasözleri, deyimler ve isimlerde geniş yer bulduğunu ve adalet, güç, cesaret, başarı ve yiğitlik gibi değerlerin sembolü olduğunu belirtmektedir. ${ }^{6}$ Tülin Çoruhlu ise İslamiyet'ten önce ve sonra Türkler arasında kılıcın kuvvet ve iktidar sembolü olarak kullanıldığını söylemektedir. ${ }^{7}$

Türklerin savaşlarda en çok kullandığı silahlardan biri kılıçlardır. Türk kılıçlarının prototipi sayılacak en eski kılıç, Altay dağlarındaki Katanda ve Kudırge kurganlanında bulunmuştur. ${ }^{8}$ Türklerin Hunlardan itibaren kılıç yapımıyla uğraştıkları ve özellikle Göktürklerden itibaren

Volume 12

Issue 4

August

2020 bütün Türk kavimlerinin kılıç yapma ve kullanma hususunda birbirleriyle yarışacak düzeyde oldukları belirtilmektedir. ${ }^{9}$ İslami dönemde Karahanlılar, Selçuklular ve Osmanlılarda kılıç yapımı devam etmektedir. Erken Osmanlı döneminden günümüze ulaşan bir kılıç bulunmamakla birlikte, Fatih döneminden 20. yüzyıl başlarına kadar yapılmış çok sayıda Osmanlı kılıcı günümüze ulaşmıştır. ${ }^{10}$ Kılıç, tarihi süreç boyunca bir saldırı silahı olmasının yanında, Osmanlı devletinde hükümdarlık alameti olarak ta karşımıza çıkmaktadır. ${ }^{11} \mathrm{Bu}$

teşekkür ederiz. Ayrıca fotoğrafları çekerek katkı sağlayan Aksaray Üniversitesi İslami İlimler Fakültesi Öğr. Gör. Mert Kocaman'a, çekim sırasında destek olan Sanat Tarihi Bölümü Lisans öğrencileri Eren Işık ve Tayyip Erdoğan Öz'e, kılıçların çizimlerini yapan Sanat Tarihi Bölümü Yüksek Lisans öğrencileri Hümeyra Türk ve Ela Özkan ile Lisans öğrencisi Zehra İpteş'e ve kılıçların üzerinde bulunan metinlerin okunmasına katkı sağlayan Sanat Tarihi Uzmanı Selman Şahin'e teşekkür ederiz.

2 T. Nejat Eralp, Tarih Boyunca Türk Toplumunda Silâh Kavramı ve Osmanlı İmparatorluğunda Kullanılan Silâhlar, Ankara 1993, s.45.

${ }^{3}$ https://sozluk.gov.tr/ (E.T. 20.02.2020)

${ }^{4}$ Mihrican Çolak, "Türkçenin Söz Varlığında "Kılıç", Uluslararası Türkçe Edebiyat Kültür Eğitim Dergisi, S.7/4, 2018, s.2155.

${ }^{5}$ Nebi Bozkurt, "Kılıç”, Türkiye Diyanet Vakfi İslam Ansiklopedisi, C.25, Ankara 2002, s.405.

${ }_{7}^{6}$ Çolak, agm, s.2182-2183.

7 Tülin Çoruhlu, "Tasvirlere Göre Selçuklu Silahları ve Bu Silahların Osmanlılardaki Devamı”, VI. Millı̂ Selçuklu Kültür ve Medeniyeti Semineri Bildirileri, 16-17 Mayıs 1996, Konya 1997, s.52.

${ }^{8}$ Bozkurt, agmd, s.53.

${ }^{9}$ Hilmi Aydın, Sultanların Silahları, İstanbul 2007, s.53.

${ }^{10}$ Age, s.70-76.

11 Bunun ilk uygulamalarının Asr-1 Saâdet'e kadar uzandığı, Hz. Peygamber'in savaşlarda kılıç kuşandığı ve sahâbîlere de kuşattığı bilinmektedir. Abbasi halifeleri ve birçok Türk devletinin hükümdarı tahta çıkarken kılıç kuşanmış ve bu adet Osmanlılara da geçmiştir. Bkz. Abdülkadir Özcan, "Kılıç Alayı", Türkiye Diyanet Vakfi İslam 
dönemde ilk kez Yıldırım Bayezid'in kılıç kuşandığı ve kılıç kuşanmanın I. Ahmed döneminden itibaren daha törensel bir nitelik kazanarak kılıç alayına dönüştüğü görülmektedir. ${ }^{12}$ Son kılıç alayı ise VI. Mehmet (Vahdettin)' in tahta çıkışı sırasında, 1918 yılının Ağustos ayında yapılmıştır. ${ }^{13}$ Ayrıca hükümdarların birbirlerine ve muzaffer komutanlarına şeref sembolü olarak kılıç hediye ettikleri de bilinmektedir. ${ }^{14}$

K1lıçlar genel olarak kabza, balçak, namlu ve kın bölümlerinden oluşmaktadır. ${ }^{15}$ Arapça "tutmak, avuca almak" fiilinden ortaya çıkan kabza, kılıcın önemli bölümlerinden biri olup, elle tutulan kısmıdır. ${ }^{16}$ Balçak, kabza ve namlu arasında bulunur ve savaş sırasında elin korunması için siperlik görevi üstlenir. ${ }^{17}$ Namlu ya da taban olarak isimlendirilen yer ise k1lıcın asıl gövdesi ve kesici bölümüdür. ${ }^{18}$ Kılıçları dış etkenlere karşı muhafaza eden kınlar, çoğunlukla ahşap malzemeden yapılıp, dış kısımları deriyle kaplanmıştır. Üzerlerinde ağızlık, çamurluk, bilezik ve taşıma halkaları mevcuttur. ${ }^{19}$

\section{Eserlerin Tanıtılması}

Eser No 1: Müzenin envanterinde Numarasız/1350 şeklinde kaydedilen kılıç (yatağan), 80,5 x 2,5 cm ölçülerindedir. Kını bulunmayan kılıcın namlusu ve kabzası demirdendir. Kabzanın yüzeyi kıvrım dallar üzerinde bir kısmı açmış, bir kısmı ise tomurcuk haldeki beş yapraklı çiçekler ve lalelerle süslenmiştir. Süslemenin zemini zikzak şeklinde taranmıştır. Kabzayla namlunun birleşme noktasında bulunan kısımda altın kakma tekniğinde nesih hattıyla; "Bıçağımdan hazr kılsın susamış fani düşmana", "Siperkâr eylemez asla güvenip kerem-i

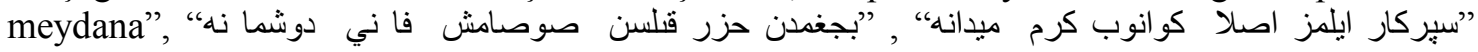
yazılmıştır. Bu kısmın kenarları helezonik şekillerle süslenmiştir. Kılıcın diğer yüzü de aynı motiflerle bezenmiştir ancak burada "Salınca hamlesin her dem şakır şimşek gibi gör kim", "Bunun sahibi Konyava-yi Osman'dır ne merdane", "صالنجه حملسن هر دم شاقر شيمشك كبي كركيم" "yazılıdır. Eser formu ve kabzasındaki süslemelerden yola çıkılarak 17. yüzyıla tarihlendirilebilir (Fot. 1-3, Çizim 1-4). Sahibinin Konyalı olması, kılıcın Konya'da yapıldığını düşündürmektedir.

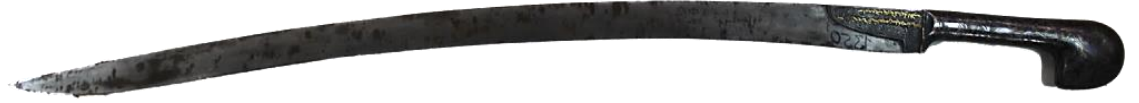

Fot. 1: Numarasız/1350 Envanter Numaralı Kılıç

Ansiklopedisi, C.25, Ankara 2002, s.408; Ahat Ural Bikkul, "Topkapı Sarayı Müzesindeki Türk Kılıçları Üzerinde Bir İnceleme”, Türk Etnografya Dergisi, S.IV, Ankara 1962, s.22.

12 Özcan, agmd, s.408-409.

${ }^{13}$ Aydın, age, s.60; Özcan, agmd, s.410.

${ }^{14}$ Bikkul, agm, s.22; Aydın, age, s.32.

${ }^{15}$ Eralp, age, s.58.

${ }^{16}$ Age, s.58.

${ }^{17}$ Bikkul, agm, s.24; Aydın, age, s.50.

${ }^{18}$ Eralp, age, s.60; Aydin, age, s.50.

${ }^{19}$ Eralp, age, s.63; Aydın, age, s.51. 


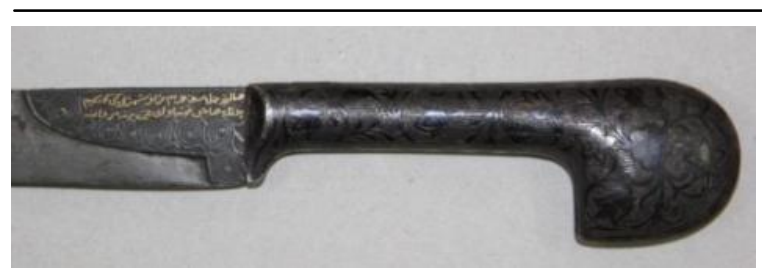

Fot. 2: Numarasız/1350 Envanter Numaralı Kılıç

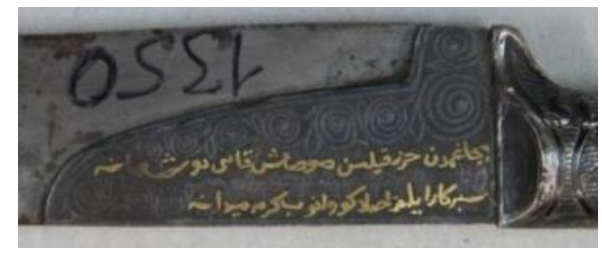

Fot. 3: Numarasız/1350 Envanter Numaralı Kılıç

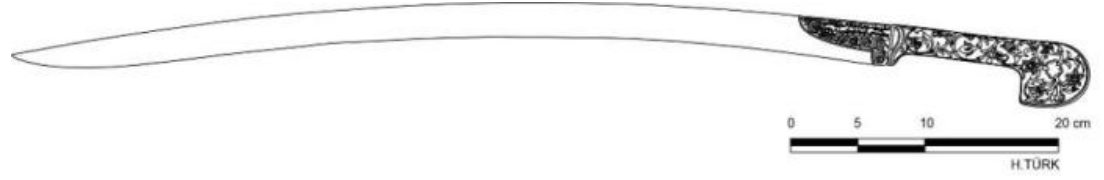

Çizim 1: Numarasız/1350 Envanter Numaralı Kılıç

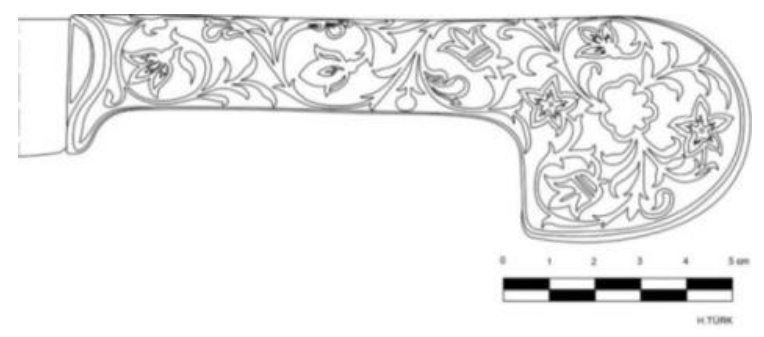

Çizim 2: Numarasız/1350 Envanter Numaralı Kılıç

Volume 12

Issue 4

August

2020

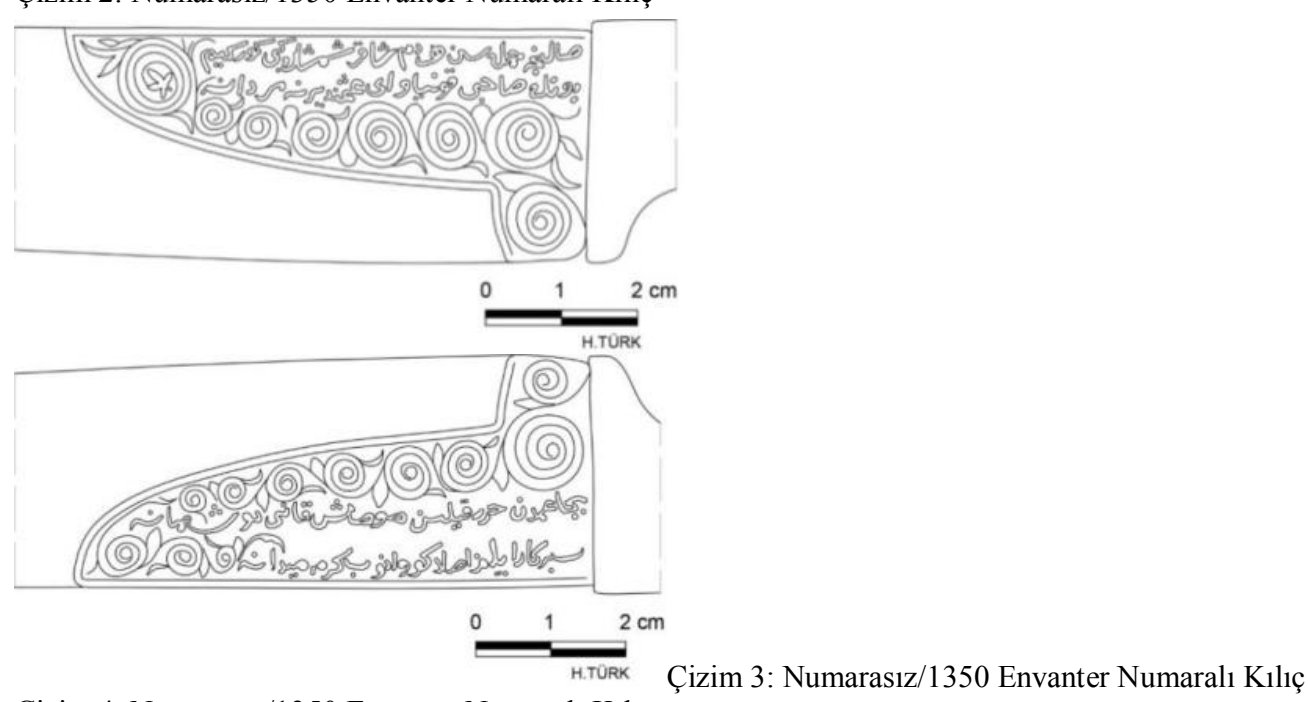

Çizim 4: Numarasız/1350 Envanter Numaralı Kılıç

Eser No 2: 1561/2635 envanter numarasına kayıtlı kılıç (yatağan), 60,5 x 4 cm ölçülerinde olup, kabzası ahşaptan, namlusu demirdendir. Üzerinde herhangi bir süsleme bulunmayan kılıç, formundan yola çıkılarak 18-19. yüzyıla tarihlendirilebilir (Fot. 4, Çizim 5). Eserin kını mevcut değildir. 


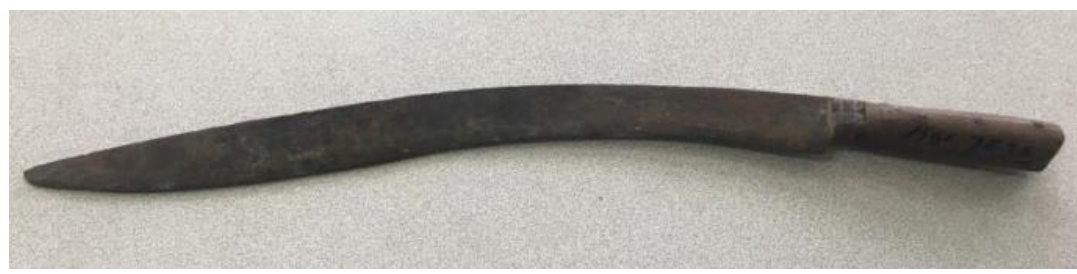

Fot. 4: 1561/2635 Envanter Numaralı Kılıç

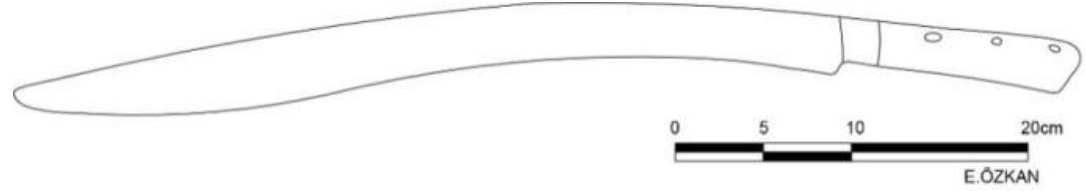

Çizim 5: 1561/2635 Envanter Numaralı Kılı̨̧

Eser No 3: Müzenin 31/2684 envanter numarasına kayıtlı olan kılıç (yatağan), 60,5 x $3 \mathrm{~cm}$ ölçülerindedir. Kını bulunmayan kılıcın kabzası ahşaptan, namlusu ise demirdendir. Üzerinde herhangi bir süsleme ve tarih ibaresi yer almayan k1lıcı, formundan dolayı 18-19. yüzyıla tarihlendirmek mümkündür (Fot. 5, Çizim 6).

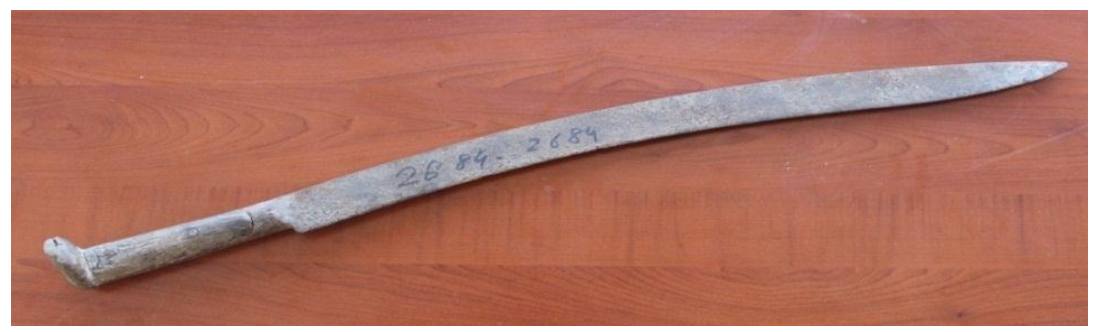

Fot. 5: 31/2684 Envanter Numaralı Kılıç

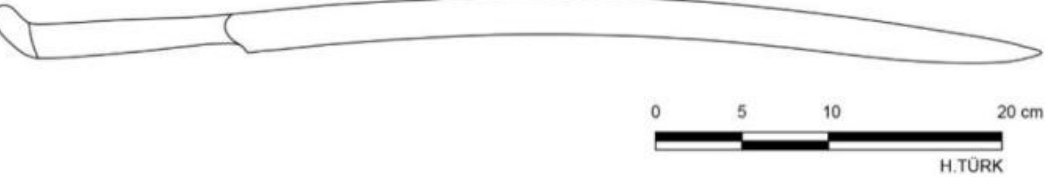

Çizim 6: 31/2684 Envanter Numaralı Kılı̨̧

Eser No 4: Müzede 1554 A/2617 envanter numarasına kayıtlı kılıç (yatağan) 80 x $5 \mathrm{~cm}$ ölçülerindedir. Kabzası boynuzdan, kulaklı biçimde süslemesiz olarak yapılmıştır. Kabzanın hemen altında, namlunun üzerindeki üçgen bölümde kazıma tekniğinde basit daire biçimli süslemeler görülmektedir. Kılıcın demirden yapılan namlusu üzerinde gümüş kakma tekniğinde yapılmış çeşitli geometrik şekiller ve papatya benzeri bitkisel motiflere yer verilmiştir. Kılıcın uç kısmında ise çizgisel süslemeler mevcuttur. Eserin diğer yüzeyinde "Yemlihâ-MekselînâMislînâ-Mernûş-Debernûş-Şâzenûş-Kefeştatayyûş-Kıtmîr”, “يملحا مكسلينا مسلنا مرنوش دبرنوش "A "شازنوش كفتشطيوش=قطعير" ş̧ yakın mesafede, tuğra biçimli "Sene 1217 Muhammed" yazısı görülmektedir. Kıllı̧ üzerinde bulunan yazıların tamamı gümüş kakmadır. Kılıcın ahşaptan yapılan kını deriyle, ağızlık ve çamurluk kısmı metalle kaplanmıştır. Üzerindeki tarih ibaresinden kılıcın 1217/1802-1803 tarihli olduğu anlaşılmaktadır (Fot. 6-8, Çizim 7-9). 


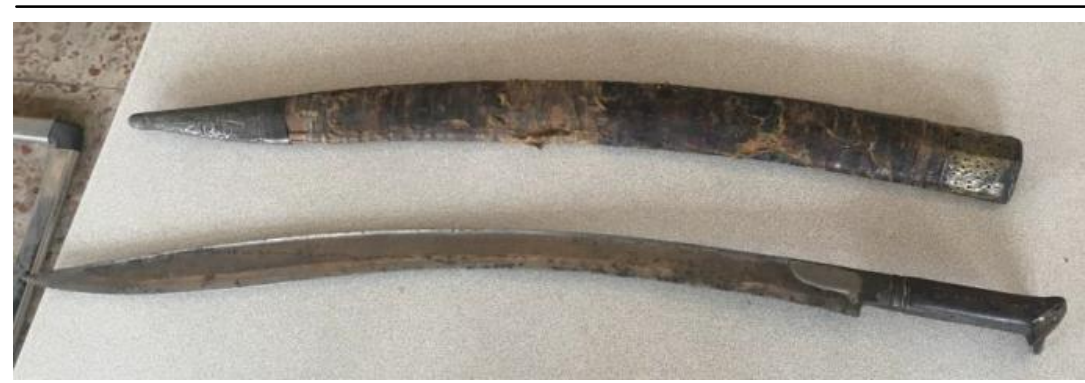

Fot. 6: 1554 A/2617 Envanter Numaralı Kılıç

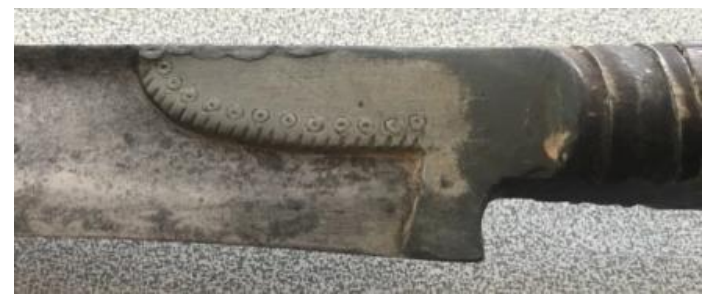

Fot. 7: 1554 A/2617 Envanter Numaralı Kılıç

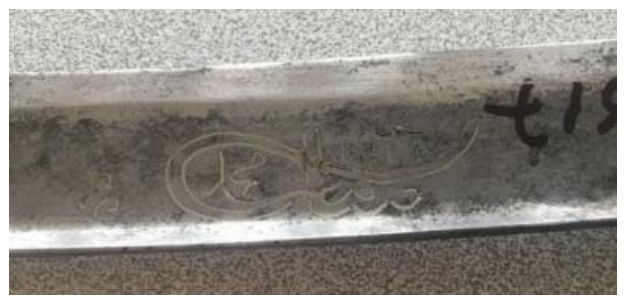

Fot. 8: 1554 A/2617 Envanter Numaralı Kılıç
HISTORY STUDIES

1921

Volume 12

Issue 4

August

2020

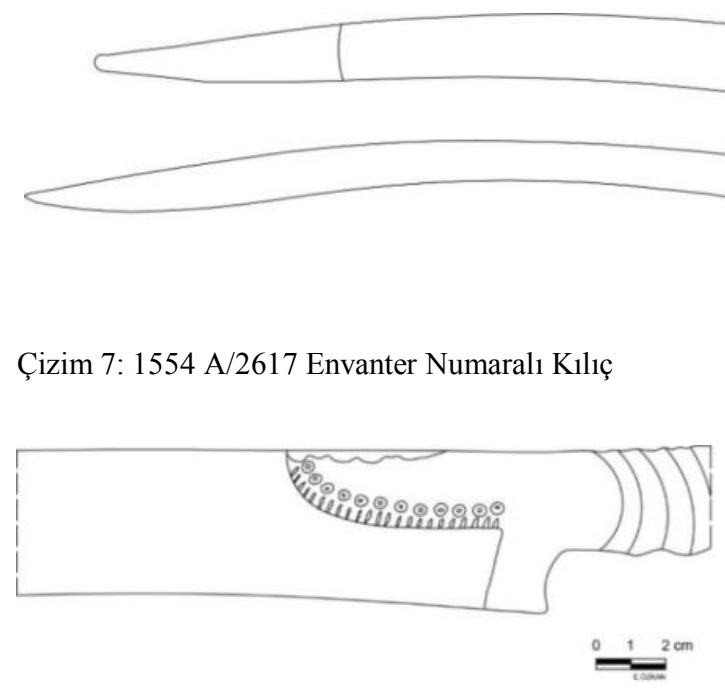

Çizim 8: 1554 A/2617 Envanter Numaralı Kılıç

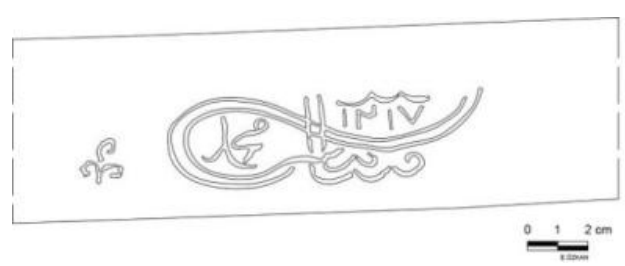

Çizim 9: 1554 A/2617 Envanter Numaralı Kılıç

Eser No 5: Müzede 1634/781 envanter numarasına kayıtlı bulunan kılıç (yatağan), 75 x 3 cm ölçülerindedir. Kılıcın kabzası boynuzdan yapılmıştır ve iki kulaklıdır. Bu kısma iri başlı çiviler yerleştirilmiştir. Kabza ve namlunun birleştiği bölümde bulunan kenarları dilimli üçgen biçimli bölümde altın kullanılmış, burası ortalarına iri başlı çiviler çakılan beş yapraklı çiçeklerle süslenmiştir. Bu bölümün sırt kısmında eşkenar dörtgen şeklinde motifler görülmektedir (Çizim 11). Eserin namlusu çelikten olup, tek olukludur. Kılıcın bir yüzünde bulunan kartuş altın kakma tekniğinde yapraklarla süslenirken, diğer yüzünde bulunan kartuş içinde ise yine altın kakma tekniğinde sülüs hattıyla "Amele Hasan, sahibi Mustafa, sene

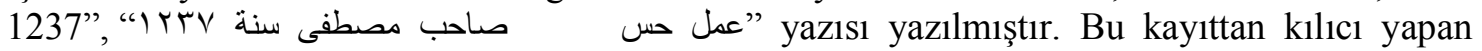
ustanın Hasan, sahibinin ise Mustafa isimli biri olduğu anlaşılmaktadır. Yapım tarihi ise 1237/1821-22'dir. Bu eserin kını müzenin 1634/782 envanter numarasına kaydedilmiştir. 75 x

\section{History Studies}


$4,5 \mathrm{~cm}$ ölçülerindeki ahşaptan yapılan ve siyah deriyle kaplanan kının ucu metaldendir. Yan tarafı kırık olan kının üzerinde herhangi bir süsleme yer almamaktadır. Envanter kaydında 17. yüzyıla tarihlendirilen eserin, üzerindeki tarih ibaresinden, 19. yüzyılda yapıldığı ortaya çıkmaktadır (Fot. 9-13, Çizim 10-14). İncelediğimiz bu yatağanla form ve süslemeler bakımından çok benzeyen başka bir örnek Kırıkkale Müzesinde yer almaktadır. ${ }^{20}$

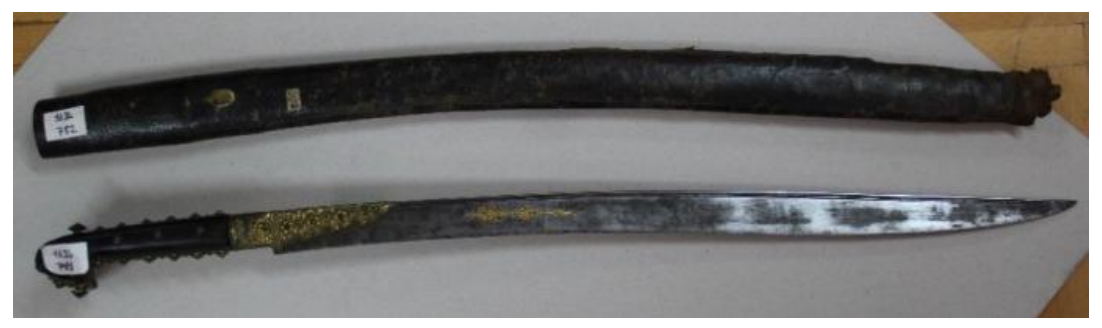

Fot. 9: 1634/781 Envanter Numaralı Kılıç

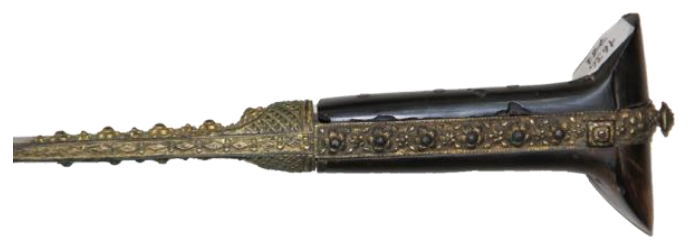

Fot. 10: 1634/781 Envanter Numaralı Kılıç

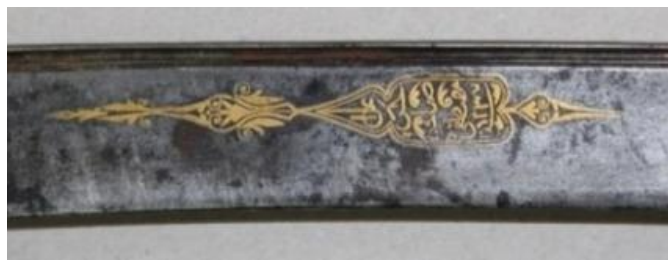

Fot 12: 1634/781 Envanter Numaralı Kılıç

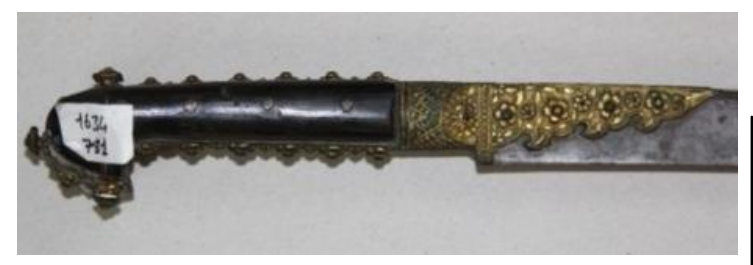

Fot. 11: 1634/781 Envanter Numaralı Kılı̨̧

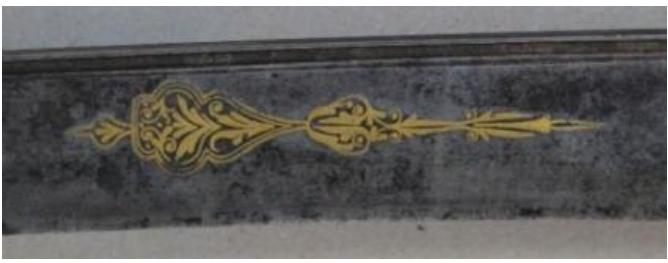

Fot. 13: 1634/781 Envanter Numaralı Kılıç
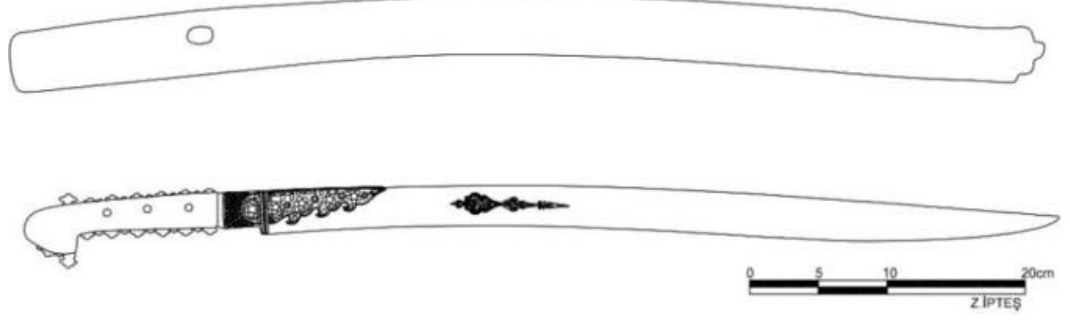

Çizim 10: 1634/781 Envanter Numaralı Kılıç
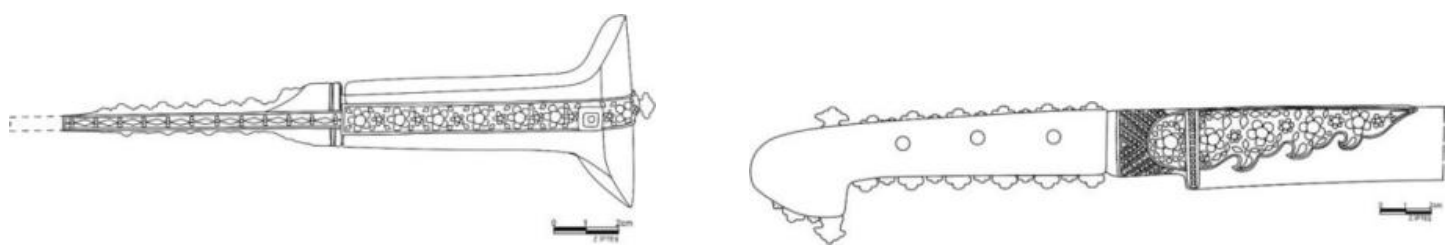

${ }^{20}$ Cemile Aydın, Kırıkkale MKEK Silah Müzesinde Bulunan Osmanlı Dönemi Silahları, (Gazi Üniversitesi Sosyal Bilimler Enstitüsü, Yayınlanmamış Yüksek Lisans Tezi), Ankara 2009, s.73-74, Resim No:51-52, s.335. 
Hacer Kara - İlker Mimiroğlu

Çizim 11: 1634/781 Envanter Numaralı Kılıç

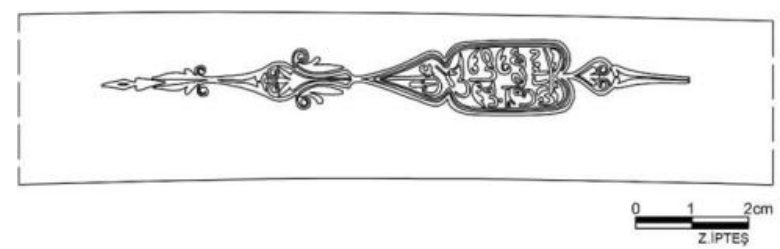

Çizim 13: 1634/781 Envanter Numaralı Kılıç
Çizim 12: 1634/781 Envanter Numaralı Kılıç

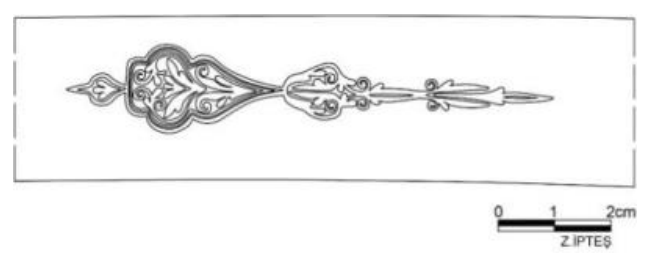

Çizim 14: 1634/781 Envanter Numaralı Kılıç

Eser No 6: Müzede 1639/783 envanter numarasına kayıtlı eser 74,2 x 2,7 cm ölçülerindedir. Kılıcın (yatağan) kemikten yapılan kabzası süslemesizdir. Kabzanın ve namlunun birleştiği noktada bulunan üçgen parça dilimli kenarlıdır. Bu parçanın tüm kenarları zikzak şeklinde kazıma tekniğinde basitçe süslenmiştir. Kılıcın namlusu çelikten yapılmıştır. Namlunun bir yüzünde kazıma tekniğinde yapılmış çizgisel süslemeler görülmektedir. $\mathrm{Bu}$ süslemenin ortasında oluşturulan kartuş içine yine kazıma tekniğinde talik hattıyla "cân-1 Ali" yazılmıştır. Kılıcın diğer yüzünde ise "sene 1314" şeklinde tarihe yer verilmiştir. Bu tarihten kılıcın 18961897 yılında yapıldığı anlaşılmaktadır (Fot. 14-17, Çizim 15-19). Eserin kını bulunmamaktadır.

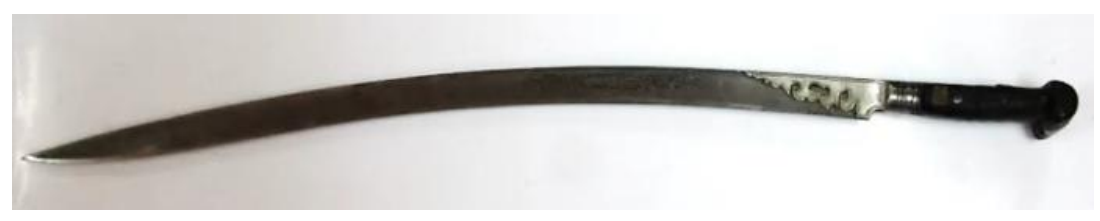

Fot. 14: 1639/783 Envanter Numaralı Kılıç

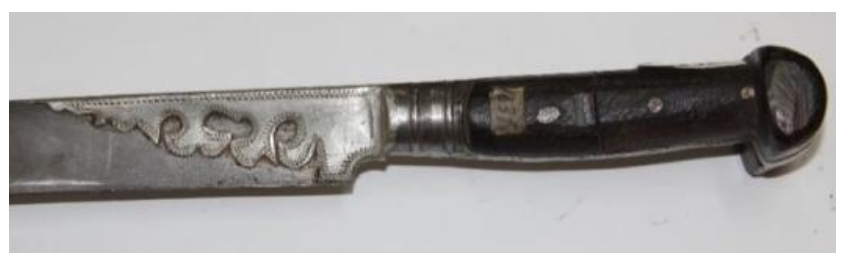

Fot. 15: 1639/783 Envanter Numaralı Kılıç

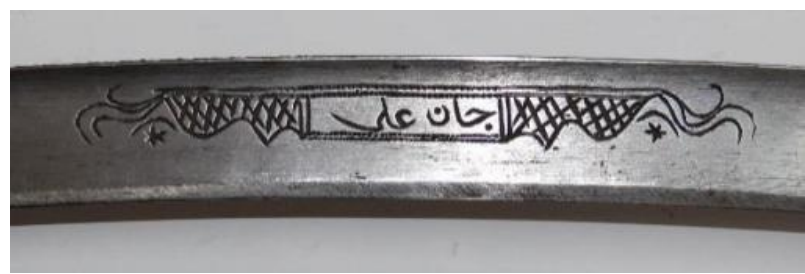

Fot. 16: 1639/783 Envanter Numaralı Kılıç

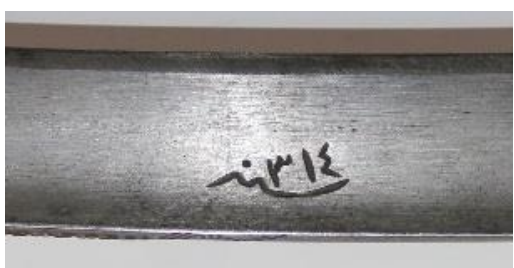

Fot. 17: 1639/783 Envanter Numaralı Kılıç

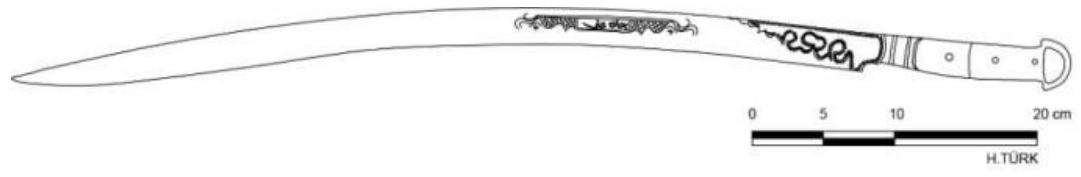

Çizim 15: 1639/783 Envanter Numaralı Kılıç 


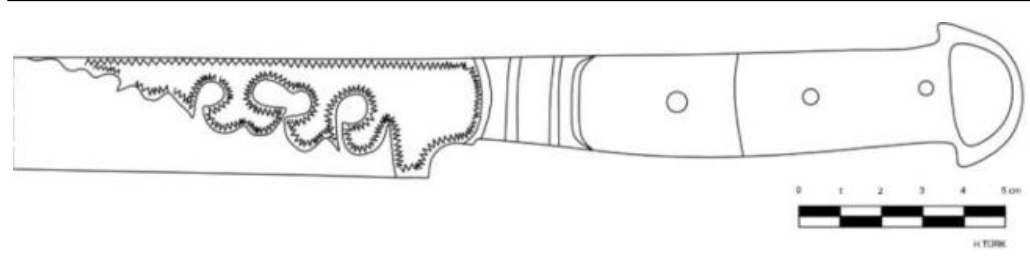

Çizim 16: 1639/783 Envanter Numaralı Kılıç

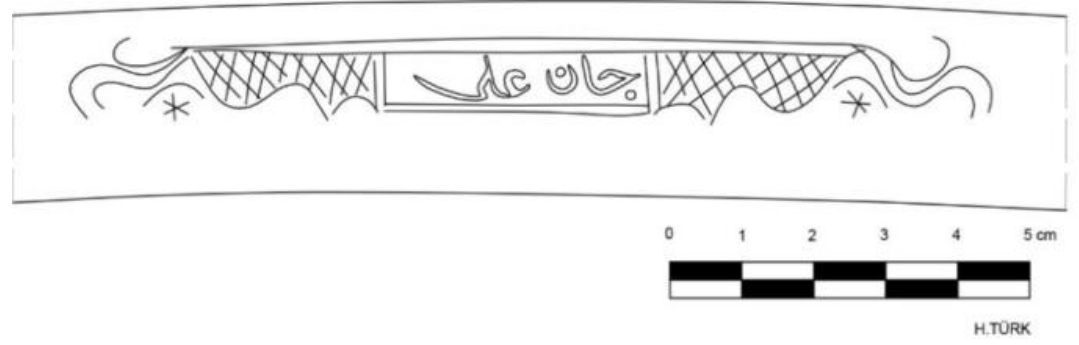

Çizim 17: 1639/783 Envanter Numaralı Kılıç

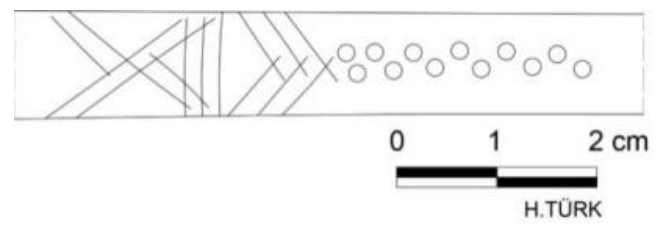

Çizim 18: 1639/783 Envanter Numaralı Kılıç

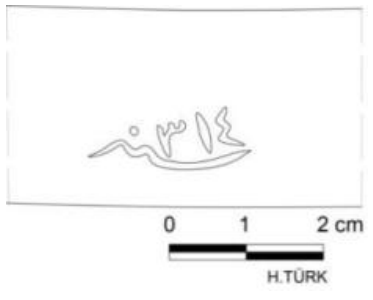

Çizim 19: 1639/783 Envanter Numaralı Kılıç

Eser No 7: 1552/780 envanter numaralı kılıç (yatağan) 96 x 3 cm ölçülerindedir. Kemikten yapılan kabzası süslemesizdir. Kabzanın hemen altında, namlunun başladığı kısımda yer alan kenarları dilimli üçgen biçimli parça zemin oyma tekniğinde yapraklarla bezenmiştir. Çelikten yapılan namlunun bir yüzünde ortada oluşturulan kartuşun içine sülüs hattıyla Ashâb-1 Kehf'in isimleri olan "Yemlihâ-Mekselînâ-Mislînâ-Mernûş-Debernûş-Şâzenûş-Kefeştatayyûş-Kıtmîr", "يملحا مكسلينا مسلنا مرنوش دبرنوش شازنوش كفشططيوش=قطمير" yazılmıştır. Kartuşun iki yanında içil eşkenar dörtgenlere bölünmüş daire biçimli süslemeler yer alır. Kılıcın oluk kısmı stilize selvi şeklinde tasarlanmış ve etrafı çeşitli geometrik motiflerle süslenmiştir. Süslemeler kazıma ve kakma tekniğindedir. Kılıcın arka kısmında ise yine bir kartuş yer almakta ve içinde geometrik süslemeler görülmektedir. Kartuşun iki yanında daire formu içinde kolları birbirinin içinden geçen biri 7 kollu, diğeri 8 kollu yıldız motifi mevcuttur. Oluk kısmının etrafındaki süslemeler öndekinin tekrarı şeklindedir. Kılıcın siyah deriden yapılan kınında süsleme bulunmamaktadır. Üzerinde herhangi bir tarih bulunmayan eser, bezeme kompozisyondan yola çı1klarak 19 . yüzyıla tarihlendirilebilir (Fot. 18-21, Çizim 20-24).

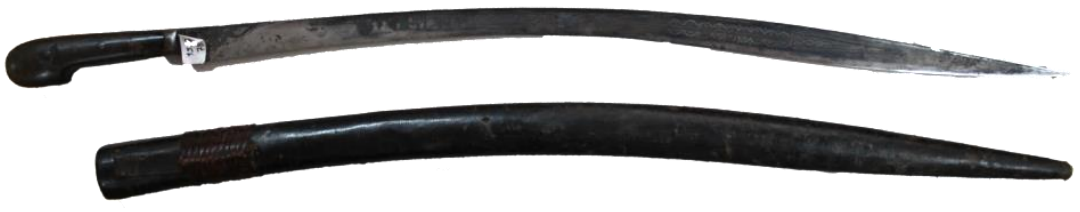


Fot. 18: 1552/780 Envanter Numaralı Kılıç

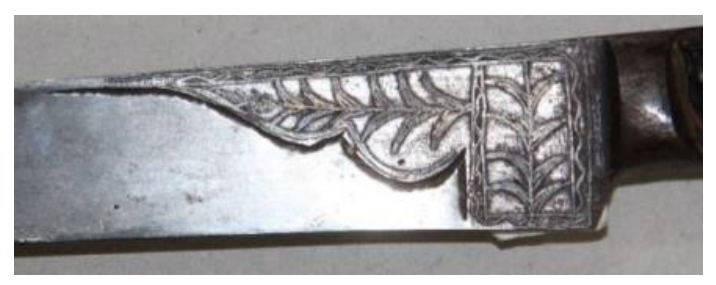

Fot. 19: 1552/780 Envanter Numaralı Kılıç

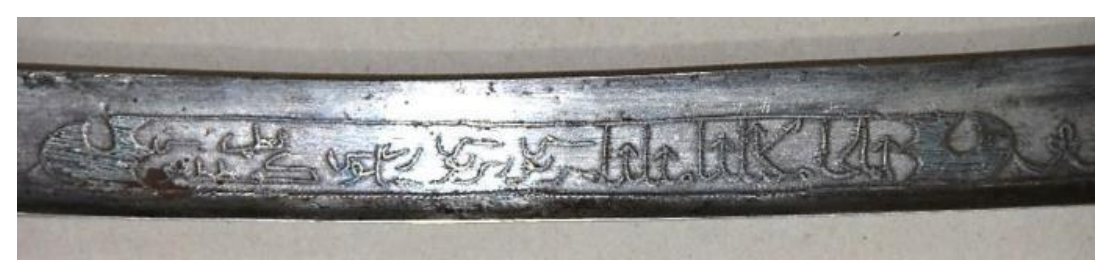

Fot. 20: 1552/780 Envanter Numaralı Kılıç

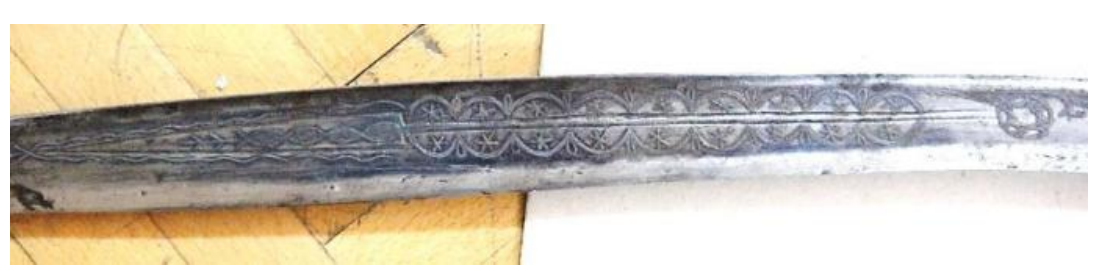

Fot. 21: 1552/780 Envanter Numaralı Kılıç

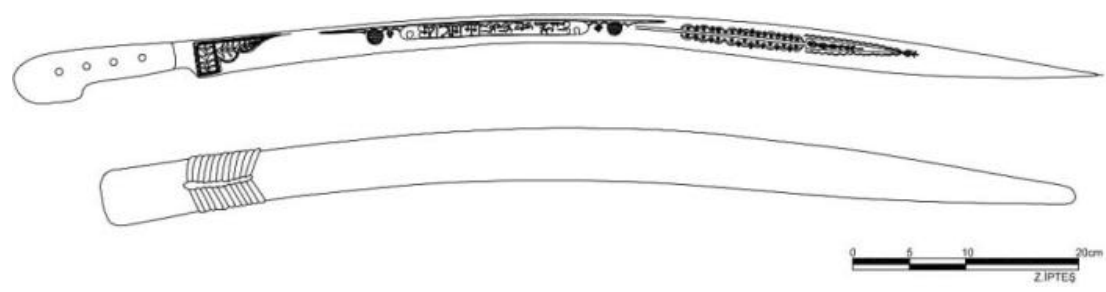

Çizim 20: 1552/780 Envanter Numaralı Kılıç

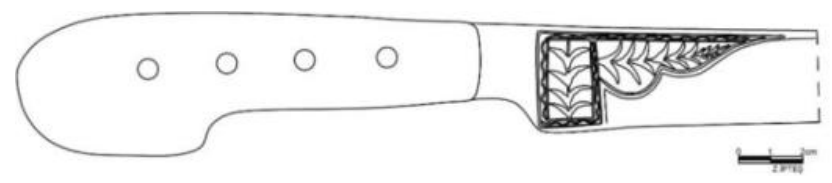

Çizim 21: 1552/780 Envanter Numaralı Kılıç

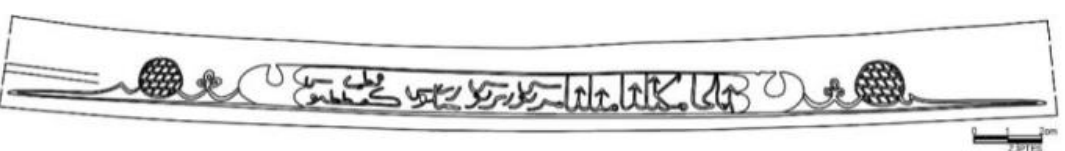

Çizim 22: 1552/780 Envanter Numaralı Kılıç 


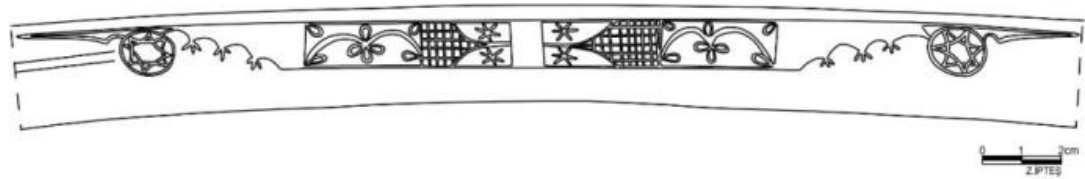

Çizim 23: 1552/780 Envanter Numaralı Kılıç

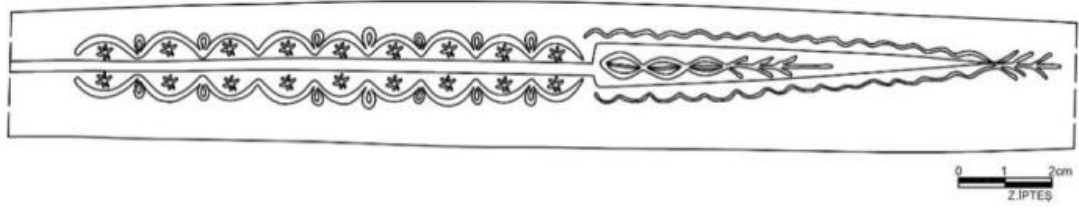

Çizim 24: 1552/780 Envanter Numaralı Kılıç

Eser No 8: $1560 / 2630$ envanter numaralı ve 72,5 x $3 \mathrm{~cm}$ ölçülerindeki kılıcın (yatağan) kabzası yok olmuştur. Kılıcın demirden yapılan namlusu zemin oyma tekniğinde yapılmış geometrik ve bitkisel motiflerle süslenmiştir. Süslemelerinden dolayı 19. yüzyılda yapıldığı düşünülebilir (Fot. 22-23, Çizim 25-26).

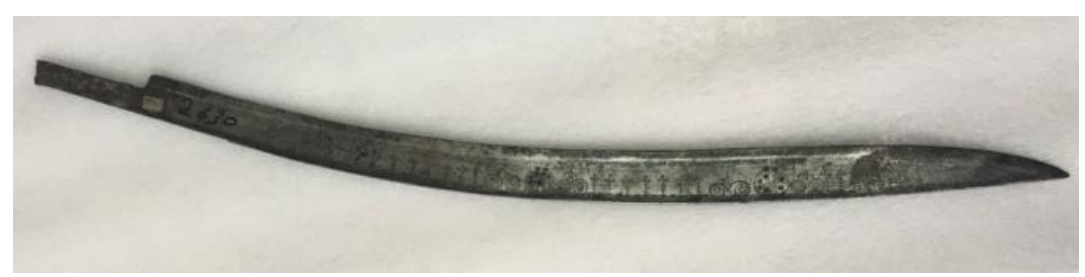

Fot. 22: 1560/2630 Envanter Numaralı Kılıç

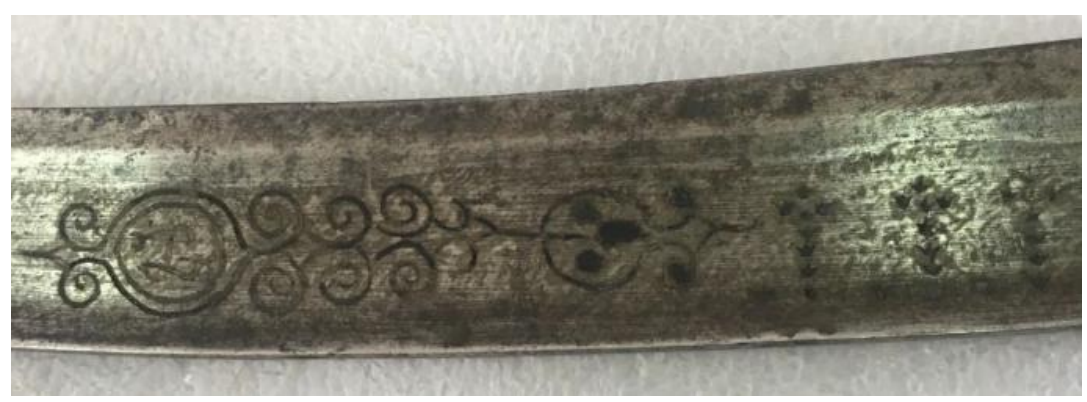

Issue 4

August

2020

Fot. 23: 1560/2630 Envanter Numaralı Kılıç

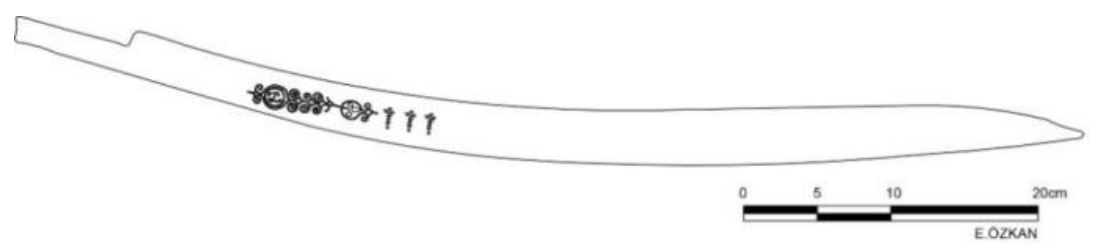

Çizim 25: 1560/2630 Envanter Numaralı Kılıç 


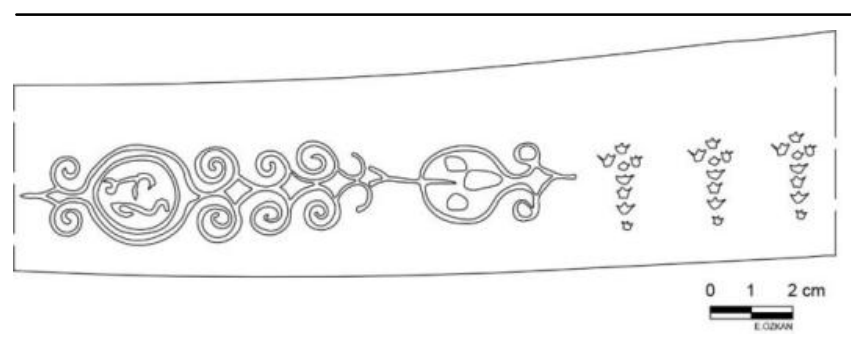

Çizim 26: 1560/2630 Envanter Numaralı Kılıç

Eser No 9: 1590/2681 envanter numarasına kayıtlı olan k1lıç (yatağan) 78,5 x 3,5 cm ölçülerindedir ve kını bulunmamaktadır. Kılıcın ahşaptan yapılan ve oldukça yıpranan kabzasında herhangi bir süsleme yer almaz. Demirden yapılan namlusunun üzerinde, kabzanın hemen altındaki üçgen biçimli ve kenarları dilimli kısım süslemelidir. Altınla süslenen bu kısımda zemin oyma tekniğinde yapılmış " $\mathrm{C}$ " kıvrımları arasında altı yapraklı çiçek motifleri göze çarpar. Kılıcın üzerinde küçük bir damga bulunmakla birlikte okunamamaktadır. Bezeme kompozisyonundan eserin 19. yüzyıla ait olduğu söylenebilir (Fot. 24-25, Çizim 27-28).

Fot. 24: 1590/2681 Envanter Numaralı Kılıç

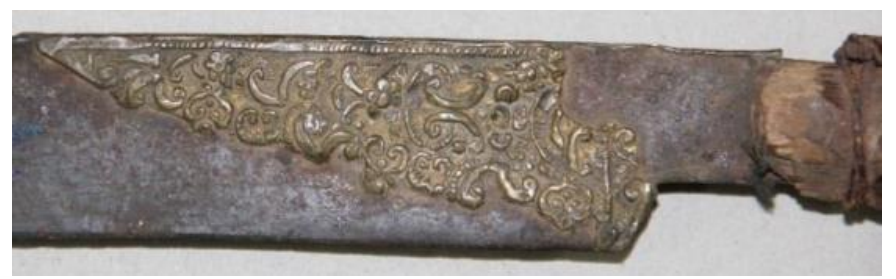

Fot. 25: 1590/2681 Envanter Numaralı Kılıç

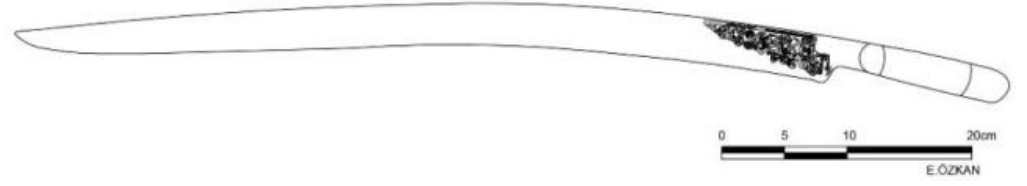

Çizim 27: 1590/2681 Envanter Numaralı Kılıç

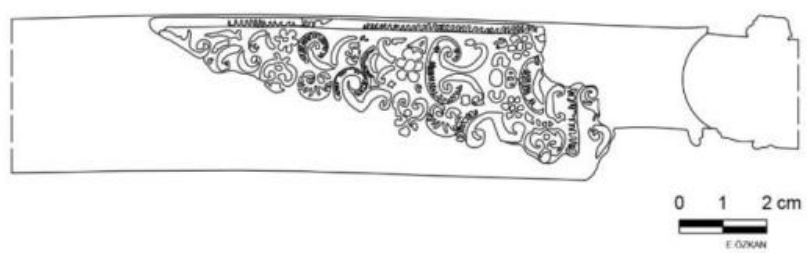

Çizim 28: 1590/2681 Envanter Numaralı Kılıç 
Eser No 10: Envanter kaydında Numarasız/2628 şeklinde kaydedilen kılıç (pala) 48 x $4 \mathrm{~cm}$ ölçülerindedir. Kabzası kemikten, balçak kısmı altın kaplama ve namlusu demirden yapılan eserin gövdesi eğridir. Kılıcın yüzeyindeki altın kakma olarak yapılmış kartuşlardan birinde sülüs hattıyla "tevekkeltü al'Allah" diğerinde ise "MâşâAllah" yazılıdır. Eserin 18-19. yüzyılda yapıldığı düşünülebilir (Fot. 26-28, Çizim 29-31). İncelenen bu örneğin form açısından benzeri Karaman Müzesinde yer almaktadır. ${ }^{21}$

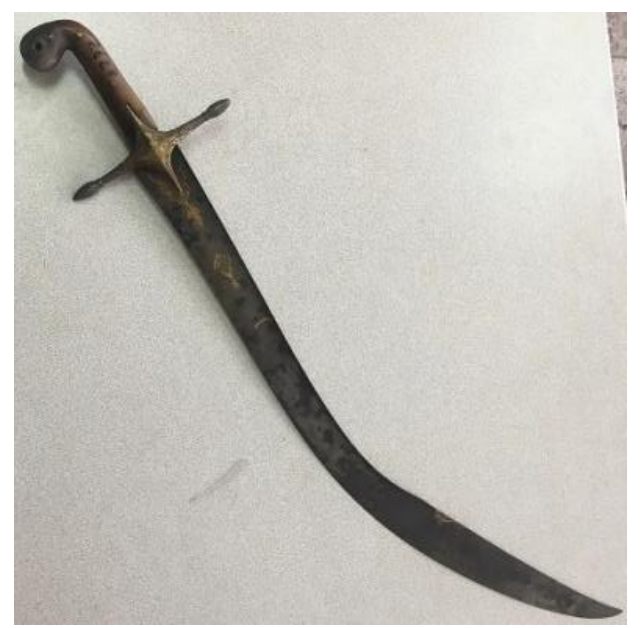

Fot. 26: Numarasız/2628 Envanter Numaralı Kılıç

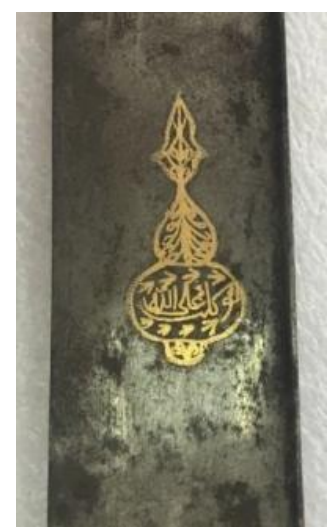

Fot. 27: Numarasız/2628 Envanter Numaralı Kılıç

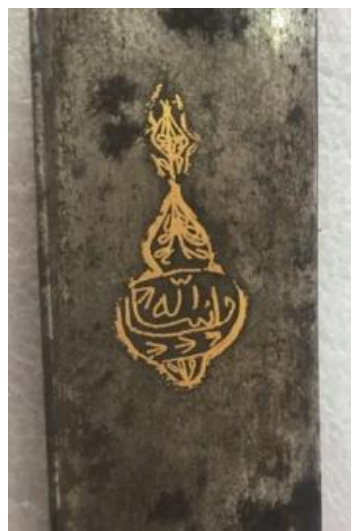

Fot. 28: Numarasız/2628 Envanter Numaralı Kılıç

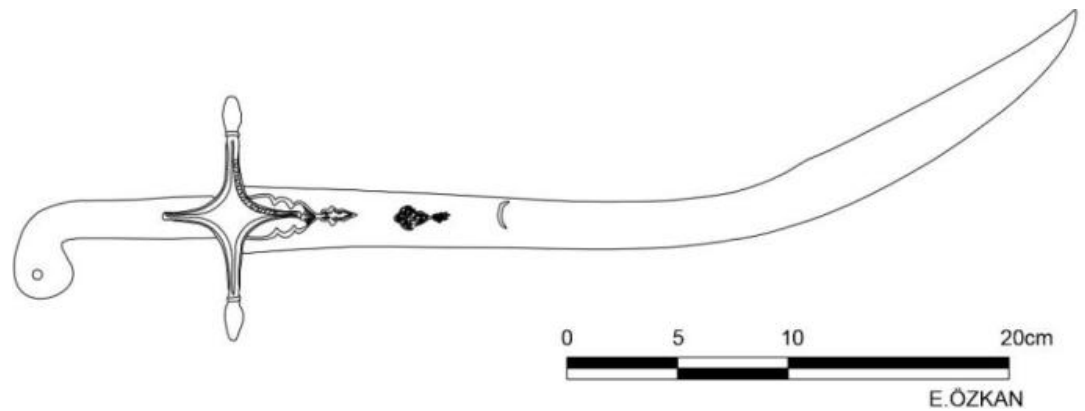

Çizim 29: Numarasız/2628 Envanter Numaralı Kılıç

${ }^{21}$ İsmail Atc1, Karaman Müzesi Etnografik Seksiyonda Sergilenen Ateşli ve Ateşsiz Silahlar, (Selçuk Üniversitesi Sosyal Bilimler Enstitüsü, Yayınlanmamış Yüksek Lisans Tezi), Konya 2014, s.57, 158, Resim No:16.

\section{History Studies}




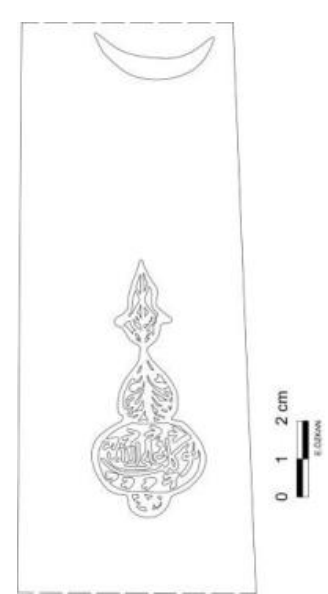

Çizim 30: Numarasız/2628 Envanter Numaralı Kılıç

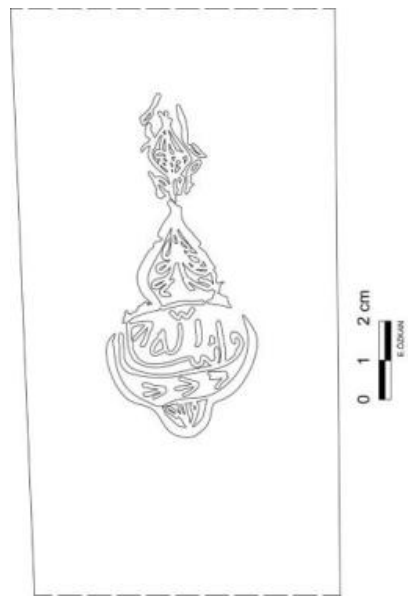

Çizim 31: Numarasız/2628 Envanter Numaralı Kılıç
Volume 12

Issue 4

August

2020

Eser No 11: Müzenin 1551/1058 envanter numarasına kayıtlı olan süvari (sabre) k1lıc1 97 x $4,6 \mathrm{~cm}$ ölçülerindedir. Kabzası ahşaptan, uçları kıvrımlı olan balçak kısmı bronzdan yapılan kılıcın uca doğru eğri olan namlusu ise çeliktendir. Eserin kınının bir kısmı bronz, bir kısmı deridendir. Kılıcın ve kınının üzerinde herhangi bir süsleme ve tarih yer almamaktadır. Formundan yola çıkarak 18-19. yüzyıla tarihlendirdiğimiz eserin (Fot. 29, Çizim 32) benzerleri Bursa Kent Müzesinde görülmektedir. Bursa Kent Müzesindeki eserlerden biri incelediğimiz kılıç gibi $97 \mathrm{~cm}$, diğeri ise $95 \mathrm{~cm}$ ölçülerinde olup, ikisi de eğri bir namluya sahiptirler. ${ }^{22}$

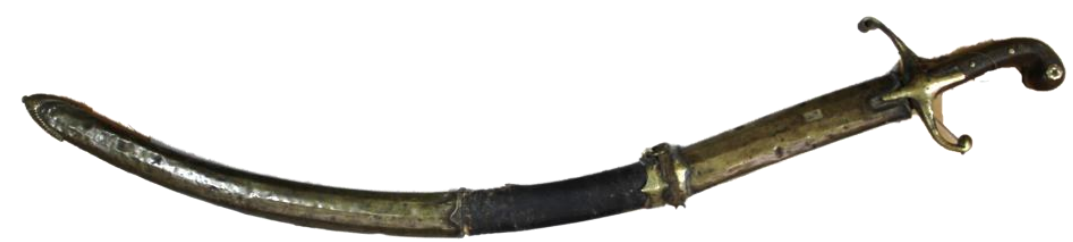

Fot. 29: 1551/1058 Envanter Numaralı Kılıç

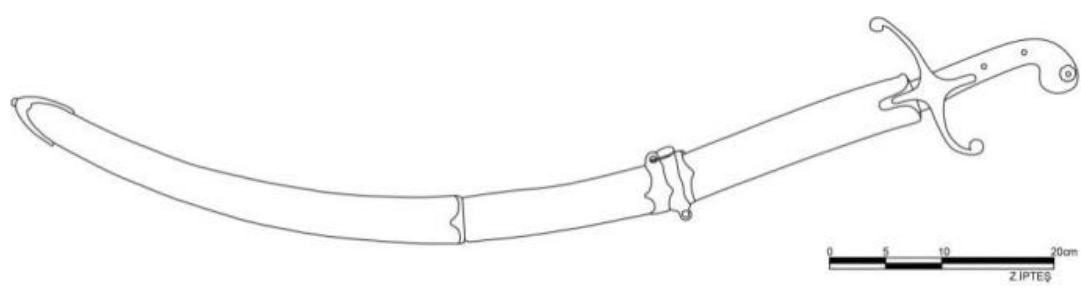

Çizim 32: 1551/1058 Envanter Numaralı Kılıç

Eser No 12: Müzenin 1553/811 envanter numarasına kayıtlı süvari (sabre) k1lıcı 89,8 x 2,9 cm ölçülerindedir. Kabzası boynuzdan, namlusu çelikten yapılan kılıç çift olukludur. Gümüşten yapılan balçağı iki yana doğru kıvrılmaktadır. Kılıcın üzerinde herhangi bir yazı ve süsleme

\footnotetext{
${ }^{22}$ Gizem Dede, Bursa Kent Müzesi Çengiç Beylikleri'ne Ait Silah Koleksiyonu, (Süleyman Demirel Üniversitesi Sosyal Bilimler Enstitüsü, Yayınlanmamış Yüksek Lisans Tezi), Isparta 2018, s.42-43, 46-47.
}

\section{History Studies}


mevcut değildir. Siyah deriden yapılan ve iki adet gümüş yüzüğü bulunan kının ucunda gümüş çamurluk bulunmaktadır. Kenarları barok kıvrımlı bitkisel süslemeli çamurluğun tam uç kısmında ise kabartma bir yılan-ejder motifi görülmektedir. Yılanın pulları ayrıntılı olarak işlenmiştir. Kılıç formu ve süslemelerinden 19. yüzyıla tarihlendirilebilir (Fot. 30-33, Çizim 33-35).

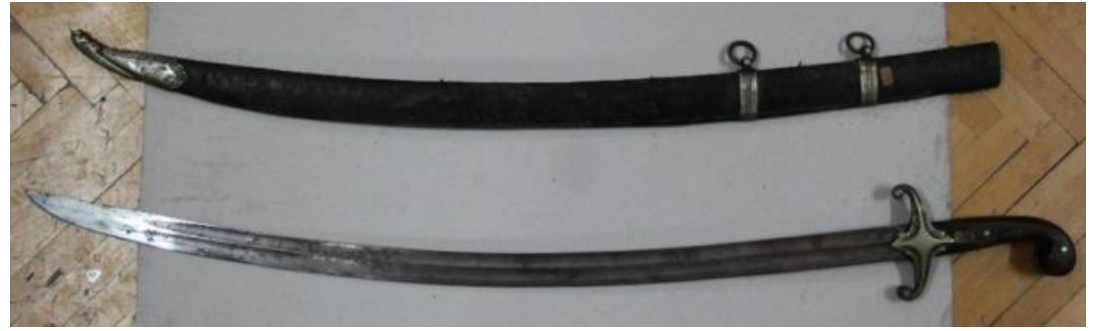

Fot. 30: 1553/811 Envanter Numaralı Kılıç

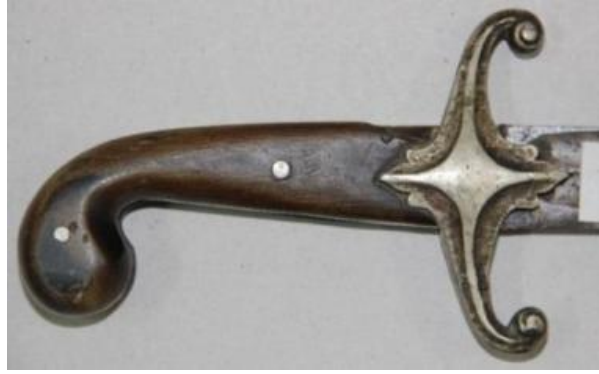

Fot 31: 1553/811 Envanter Numaralı Kılıç

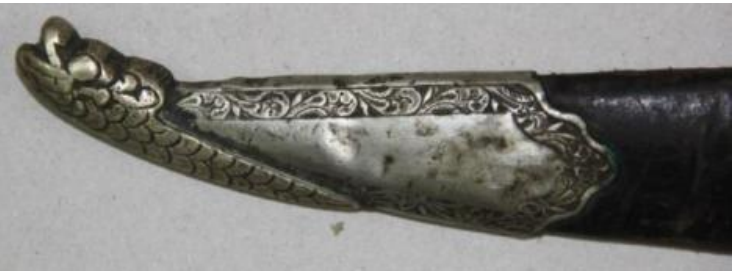

Fot 32: 1553/811 Envanter Numaralı Kılıç

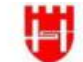

HISTORY

STUDIES

1930

Volume 12

Issue 4

August

2020

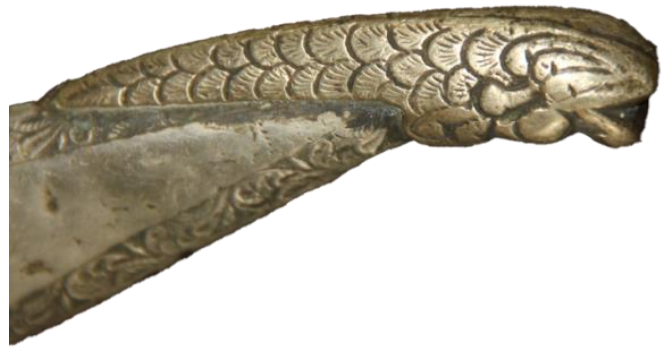

Fot. 33: 1553/811 Envanter Numaralı Kılıç
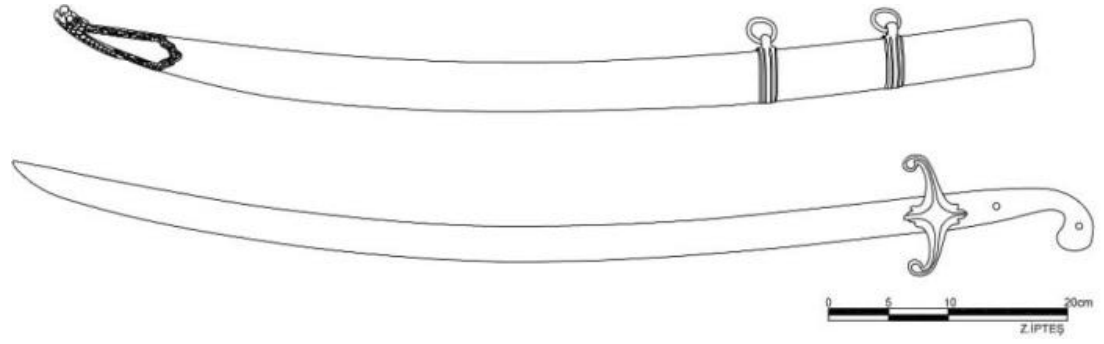

Çizim 33: 1553/811 Envanter Numaralı Kılıç 


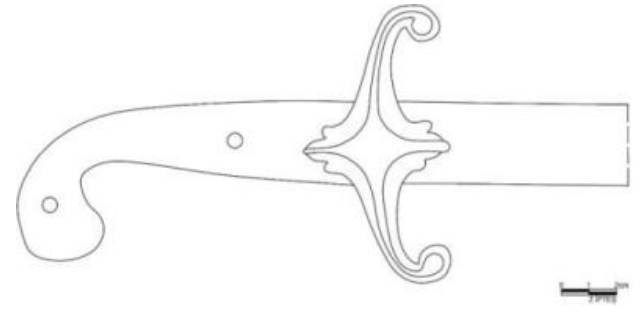

Çizim 34: 1553/811 Envanter Numaralı Kılıç

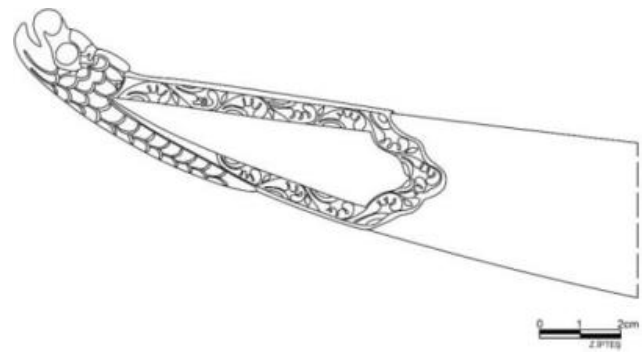

Çizim 35: 1553/811 Envanter Numaralı Kılıç

Eser No 13: 1563 A/1103 envanter numaralı süvari (sabre) k1lıc1 92 x 2,5 cm ölçülerindedir. Kabzası fildişinden, balçak kısmı gümüşten ve namlusu demirden yapılmıştır. Deriden yapılan kının ağızlık ve çamurluk kısmı ile bilezikleri gümüştendir. Çamurlukta kazıma tekniğinde çizgiler, ağızlıkta kabartma tekniğinde ay-yıldız motifleri işlenmiştir. Kılıcın tek oluklu namlusunda herhangi bir süslemeye yer verilmezken, balçak kısmında kenarların barok kıvrımlara sahip olduğu gözlenmektedir. Bu sebeple kılıcı 19. yüzyıla tarihlendirmek mümkündür (Fot. 34-37, Çizim 36-39).

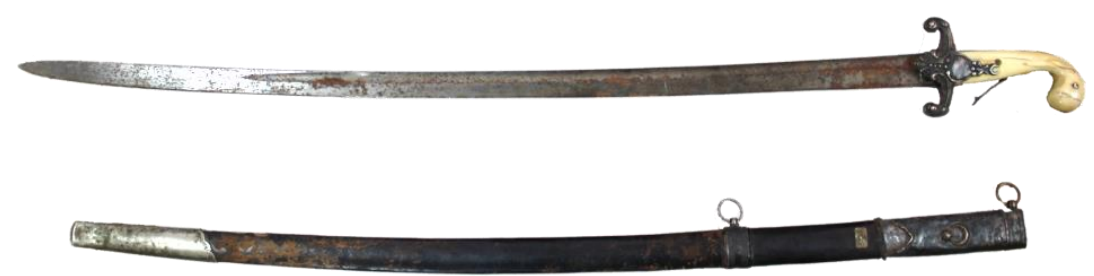

Fot. 34: 1563 A/1103 Envanter Numaralı Kılıç

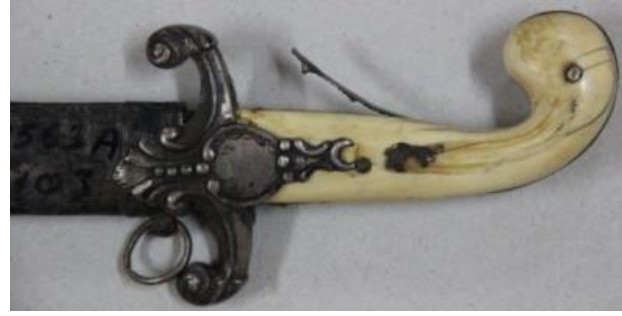

Fot. 35: 1563 A/1103 Envanter Numaralı Kılıç

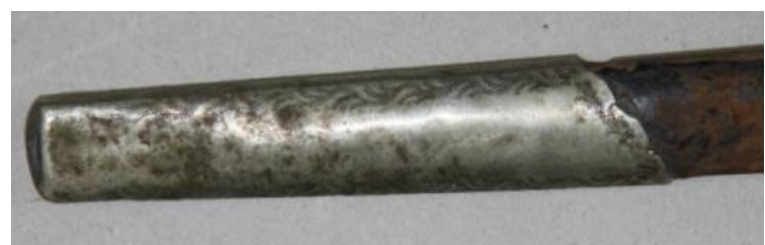

Fot. 36: 1563 A/1103 Envanter Numaralı Kılıç

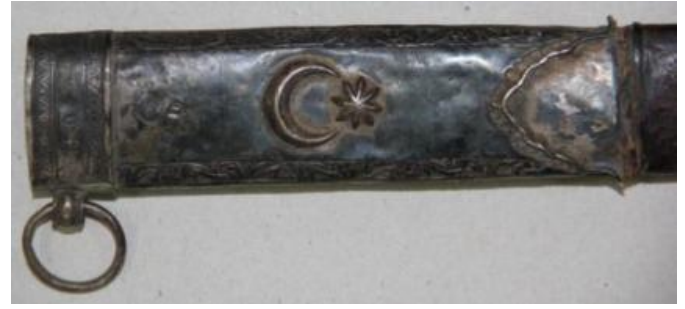

Fot. 37: 1563 A/1103 Envanter Numaralı Kılıç 


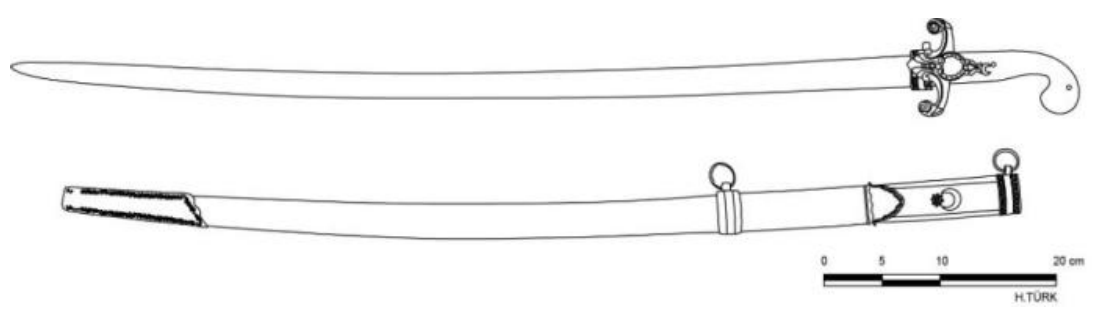

Çizim 36: 1563 A/1103 Envanter Numaralı Kılıç

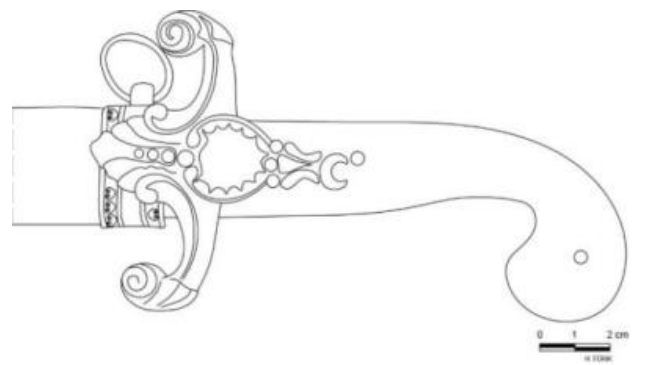

Çizim 37: 1563 A/1103 Envanter Numaralı Kılıç

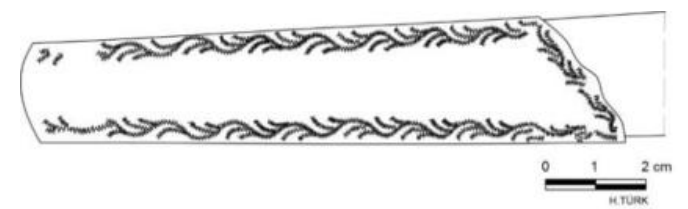

Çizim 38: 1563 A/1103 Envanter Numaralı Kılıç

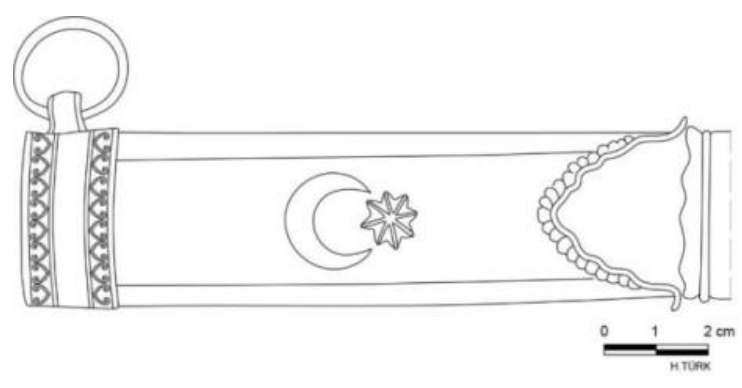

Çizim 39: 1563 A/1103 Envanter Numaralı Kılıç

Eser No 14: Müzenin 1631 A/1104 envanter numarasına kaydedilen 94 x 2,3 cm ölçülerindeki süvari (sabre) kılıcının kabzası ve balçağı altın kaplama bronzdur. Kabzanın üzerinde kazıma tekniğinde yapılmış beş yapraklı bir çiçek ve kenarlarında yapraklar görülmektedir. Kabzanın topuz kısmının yanlarında da yine kazıma tekniğinde sekiz yapraklı yıldız görünümlü bir çiçeğe yer verilirken, tepesinde iri bir yaprak göze çarpar. İki yandan volüt şeklinde kıvrılan ve üzeri kabartma çizgilerle süslenen balçağın ortasında kabzanın topuz kısmındaki çiçek tekrar edilmiştir. Eserin demirden yapılmış çift oluklu namlusunda herhangi bir süslemeye yer verilmemiştir. Kılıcın kını ahşap üzerine siyah deri kaplanarak yapılmıştır. Ağızlık ve bilezikleri altın kaplama bronzdandır. Ağızlık kısmının üzeri kazıma tekniğinde yapraklarla süslenmiştir. Bilezik kısımlarında kabza ve balçakta gördüğümüz sekiz yapraklı çiçekler tekrar edilmiştir. Deri ortadan dikilirken ince tellerin sarılarak süsleme gayesi de güdüldüğü söylenebilir. Kının ucunda bulunan metal çamurluk düşmüştür. Üzerinde herhangi bir tarih bulunmayan eser, kabza ve kınındaki süslemelerden yola çıkılarak 19. yüzyıla tarihlendirilebilir (Fot. 38-40, Çizim 40-43). 


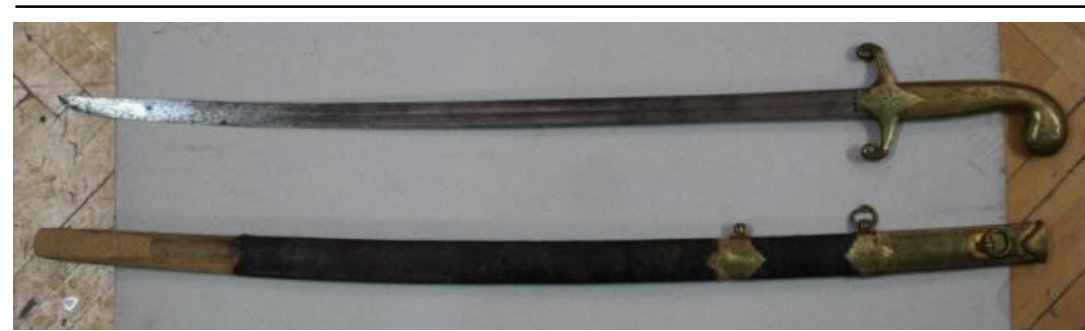

Fot. 38: 1631 A/1104 Envanter Numaralı Kılıç

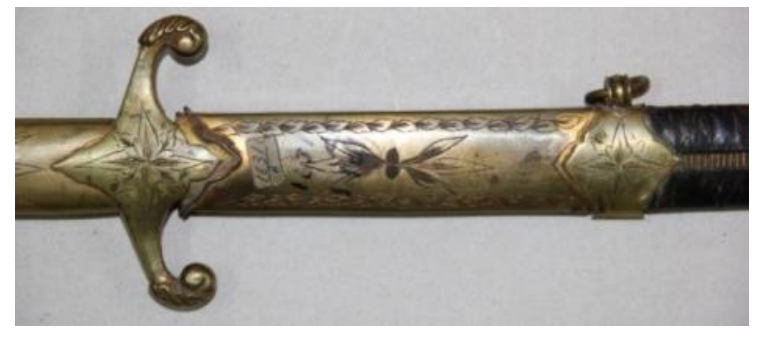

Fot. 39: 1631 A/1104 Envanter Numaralı Kılıç

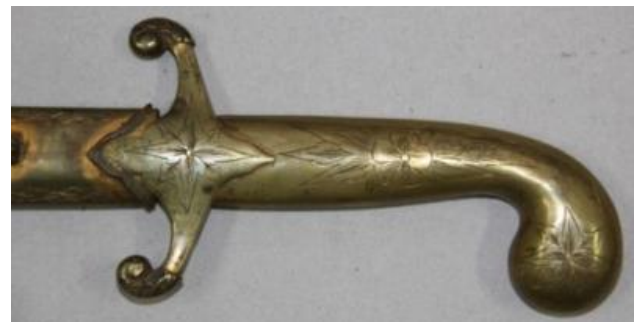

Fot. 40: 1631 A/1104 Envanter Numaralı Kılıç

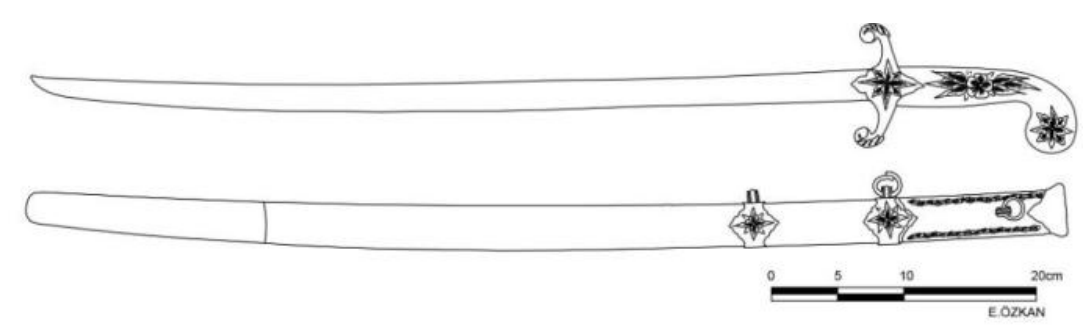

Çizim 40: 1631 A/1104 Envanter Numaralı Kılıç

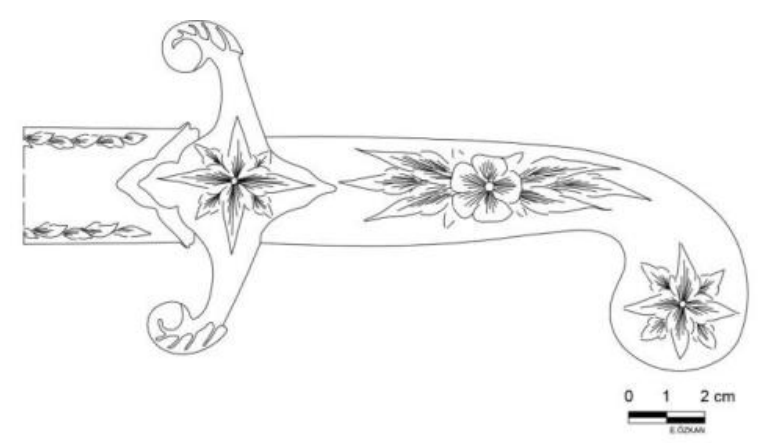

Çizim 41: 1631 A/1104 Envanter Numaralı Kılıç 


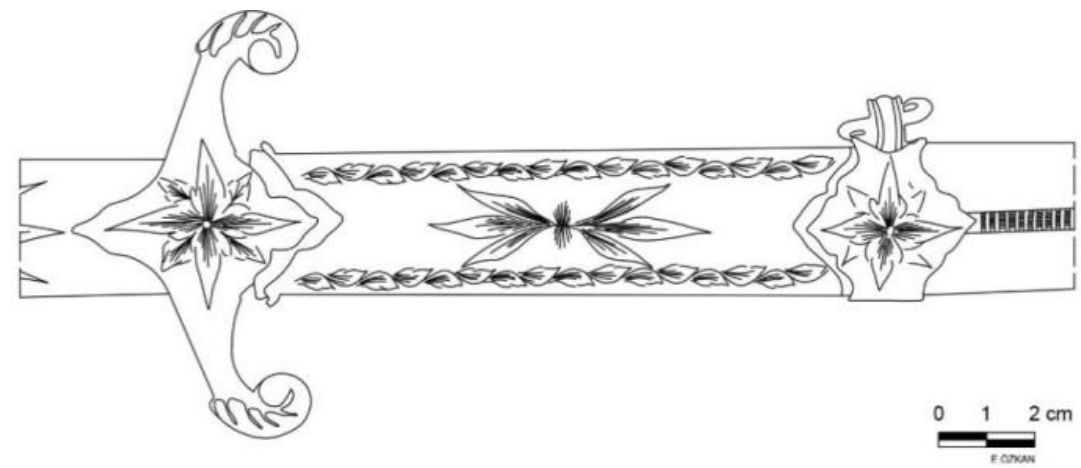

Çizim 42: 1631 A/1104 Envanter Numaralı Kılıç

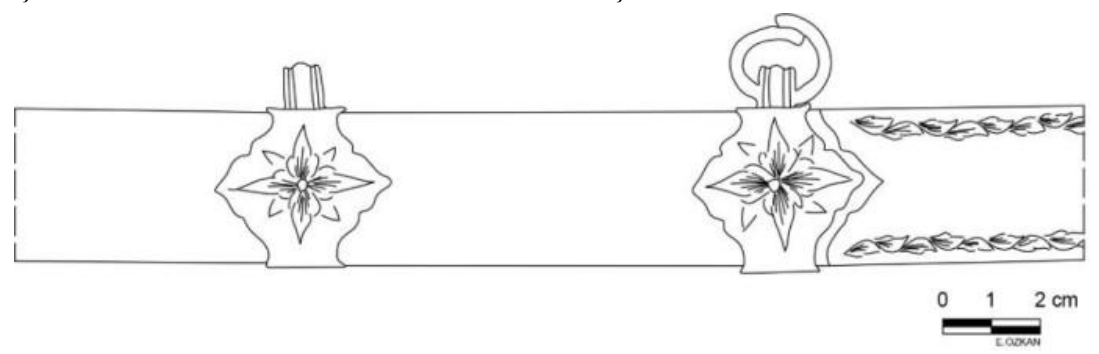

Çizim 43: 1631 A/1104 Envanter Numaralı Kılıç

Eser No 15: 360/2914 envanter numarasina kayitlı süvari (sabre) k1lıc1 96 x $3 \mathrm{~cm}$ ölçülerindedir. Kını bulunmayan eserin kabzası kemikten, tek oluklu namlusu çelikten ve balçağı bronzdan yapılmıştır. Üzerinde süsleme bulunmayan kılıç, formundan dolayı 19. yüzyıl sonlarına tarihlendirilebilir (Fot. 41, Çizim 44).

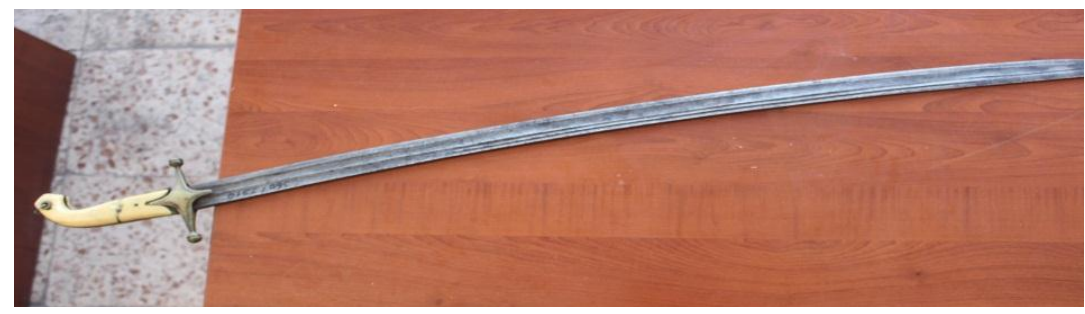

Volume 12

Issue 4

August

2020

Fot. 41: 360/2914 Envanter Numaralı Kılıç

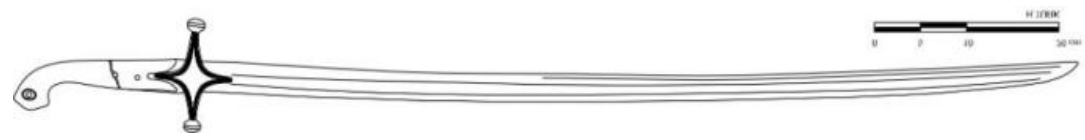

Çizim 44: 360/2914 Envanter Numaralı Kılıç

Eser No 16: Numarasız/774 envanter numarasına kayıtlı düz kılıç 93 x $2,2 \mathrm{~cm}$ ölçülerindedir. Sap kısmı yarım daire şeklinde kıvrılan, namlusu çelikten yapılan kılıcın üzeri süslemesizdir. Kını silindirik biçimde bambu ağacından yapılmıştır. Üzerinde tarih ve süsleme bulunmayan kılıç, envanter kaydında olduğu gibi 19. yüzyıla tarihlendirilebilir (Fot. 42, Çizim 
45). İncelediğimiz baston görünümlü bu düz kılıç, Karaman Müzesindeki bir örnekle benzerlik göstermektedir. ${ }^{23}$

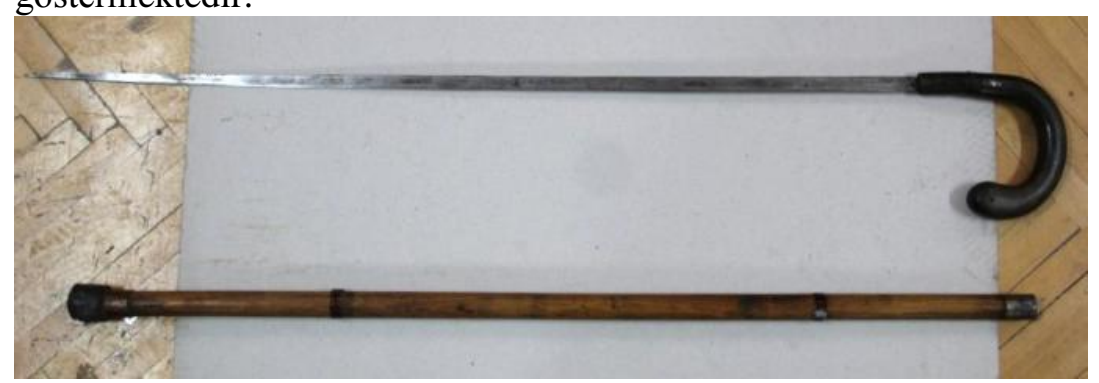

Fot. 42: Numarasız/774 Envanter Numaralı Kılıç

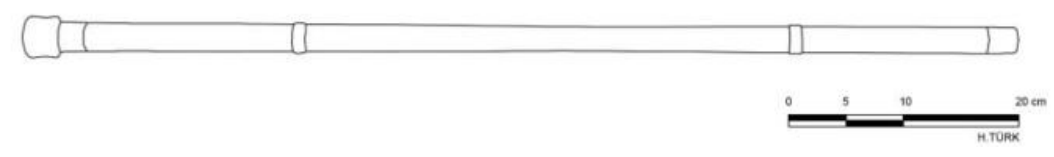

Çizim 45: Numarasız/774 Envanter Numaralı Kılıc

Eser No 17: 1562/1090 envanter numarasına kayıtlı düz kılıç 113 x 2 cm ölçülerindedir. K1lıcın altın suyuna batırılan kabzası iki boğumludur. Her iki boğumun yüzeyi "C" kıvrımlarının arasına yerleştirilmiş natüralist dallar ve papatya benzeri çiçeklerle süslenmiştir. Envanterinde Macar yapımı olduğu belirtilen kılıcın namlusu tek oluklu olup, üzerinde süsleme bulunmamaktadır. Ancak arka yüzünde IAS harfleri görülmektedir. Tahtadan yapılan kınının çamurluğu gümüş̧en olup, üzerinde yer yer dügümmlenen kıvrım dalların taşıdığı yapraklar ve tepede altı yapraklı çiçekle sonlanan bir süsleme mevcuttur. Süslemenin zemini zikzak şeklinde taranmıştır. Koyunoğlu ailesinden Pir Kemal Reis'e ait olan baston şeklindeki bu düz kılıcın, süslemelerinden dolayı 19. yüzyılda yapıldığı söylenebilir (Fot. 43-45, Çizim 46-48).

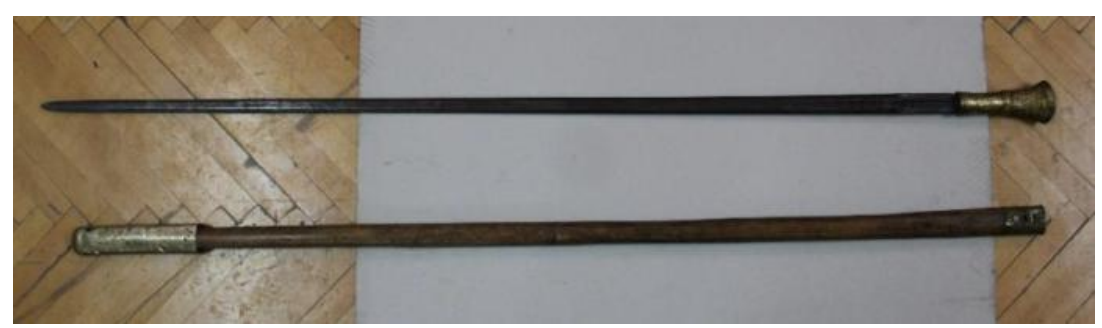

Fot. 43: 1562/1090 Envanter Numaralı Kılıç
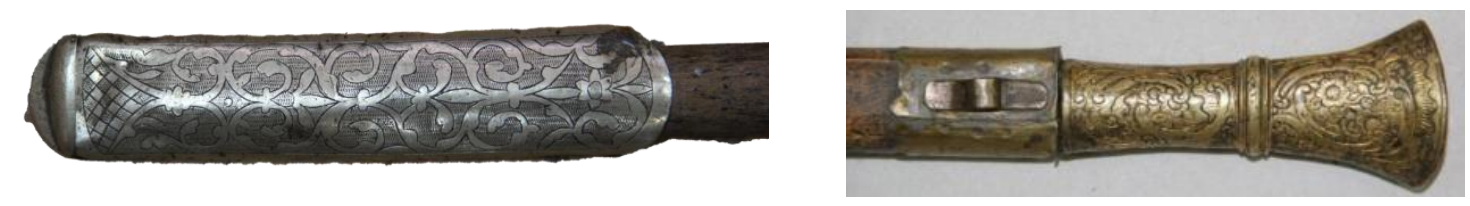

${ }^{23}$ Atc1, agt, s.76, 176, Resim No:51.

History Studies 


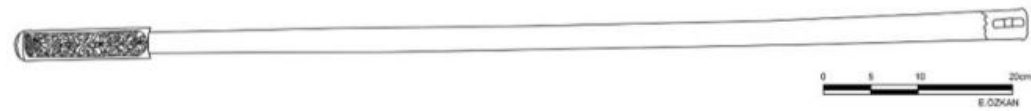

Çizim 46: 1562/1090 Envanter Numaralı Kılıç

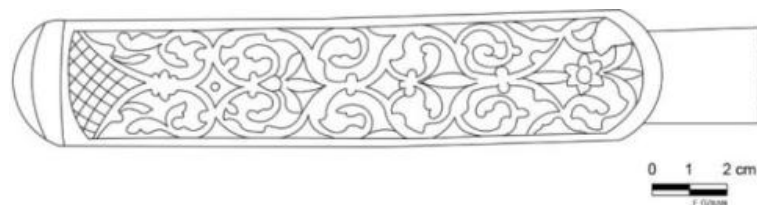

Çizim 47: 1562/1090 Envanter Numaralı Kılıç

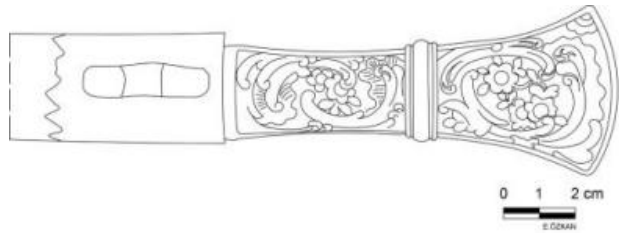

Çizim 48: 1562/1090 Envanter Numaralı Kılıç

Eser No 18: 1565 A/2682 envanter numaralı düz kılıç 72 x 3,5 cm ölçülerindedir. Kabzası, balçağı ve namlusu demirden yapılan kılıç tek olukludur. Herhangi bir süslemeye sahip olmayan kılıç ve kını envanter kaydında olduğu gibi 19. yüzyıla tarihlendirilebilir (Fot. 46-47, Çizim 49-50).

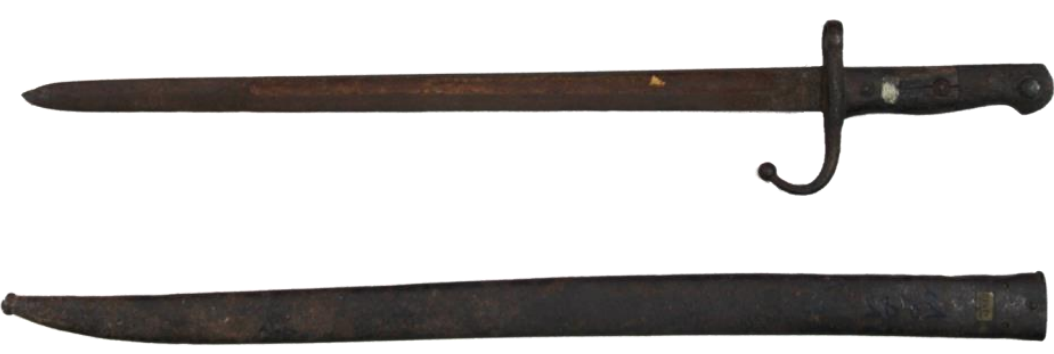

Fot. 46: 1565 A/2682 Envanter Numaralı Kılıç

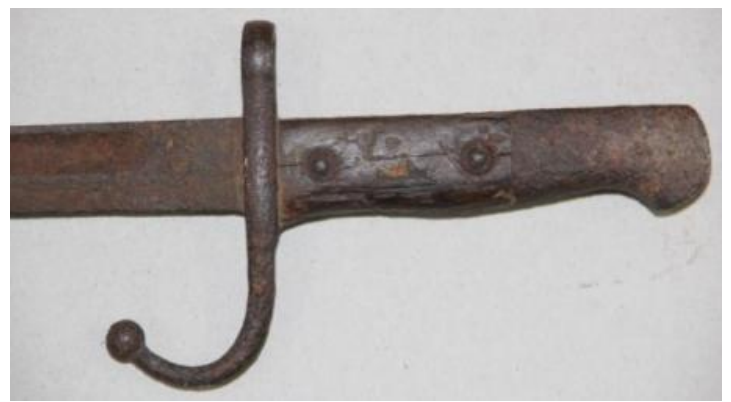

Fot. 47: 1565 A/2682 Envanter Numaralı Kılıç 


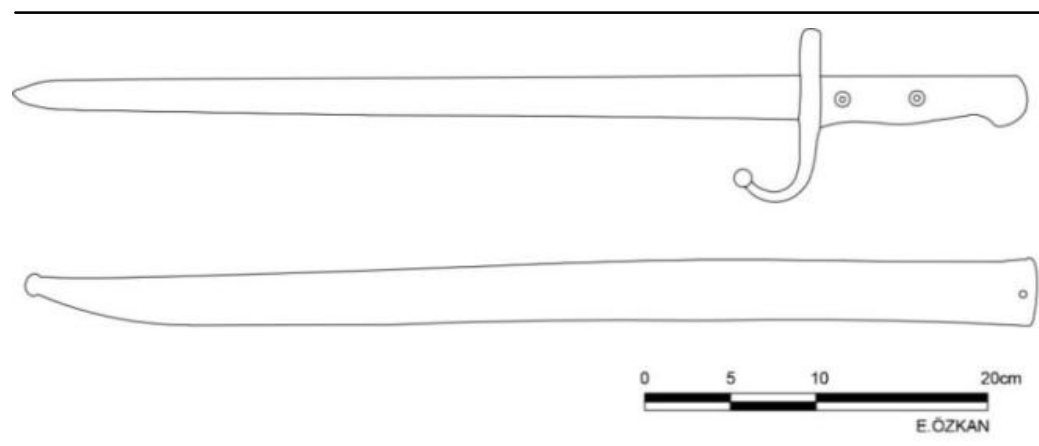

Çizim 49: 1565 A/2682 Envanter Numaralı Kılıç

Volume 12

Issue 4

August

2020

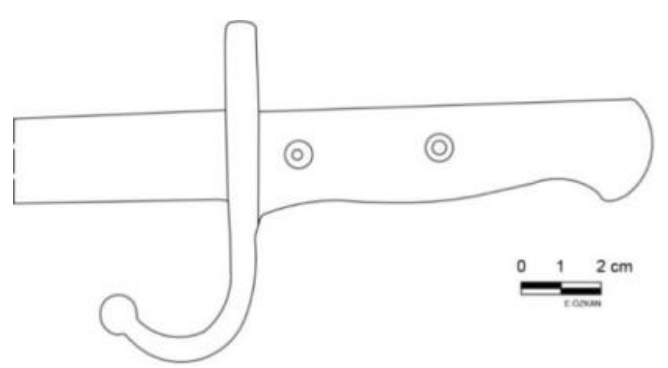

Çizim 50: 1565 A/2682 Envanter Numaralı Kılıç

Eser No 19: Müzede Numarasız/1351 envanter kaydında bulunan ucu hafif eğri kılıç 93,5 x $3,7 \mathrm{~cm}$ ölçülerindedir. Namlusu demirden ve çift oluklu olarak yapılan kılıcın kabzası kemiktendir. Kılıcın bir yüzünde kabzanın hemen altında "Eisenhauer" ${ }^{24}$ şeklinde bir yazıyla karşılaşı1maktadır. Bu yazının üzerinde göz, burun ve ağız kısmı belirgin şekilde görülen bir hilal motifine yer verilmiştir. Bu motifin üzerinde kıyafetleri, saçı, belindeki k1lıcı ve diğer unsurları ile ince ayrıntılarına kadar işlenmiş, geleneksel kıyafetleri içinde, bir Macar süvarisi resmedilmiştir. Bu askerin üzerinde "Macaristan'ım için zafer" anlamına gelen "Vincere Aut Mo Houngaria" ibaresi yer almaktadır. Onun da üzerinde başını yana çevirmiş, kanatlarını açmış vaziyette bir kartal figürü görülmektedir. Kılıç üzerinde bulunan tüm yazılar ve süslemeler kazıma tekniğindedir. Kılıcın diğer yüzünde kabzanın hemen altında "CONSTANTINOPEL" ve onun üzerinde silah tüccarı J.NIKITITS ERBEN'in adı yazmaktadır. Diğer kısımlarda ise bir önceki yüzde bulunan yazı ve figürler aynen işlenmiştir. Eserin kını mevcut değildir. Üzerinde tarih bulunmayan kılıç, envanter kaydında 17. yüzyıla tarihlendirilmiştir. Ancak kılıcın formu, süslemeleri, üzerinde Latince olarak yazılmış yazıları incelendiğinde ve silah tüccarı J.Nikitits Erben'in yaşadığı tarihler değerlendirildiğinde kılıcın 19. yüzyılın sonları, 20. yüzyılın başlarında yapıldığını söylemek mümkündür (Fot. 48-51, Çizim 51-54). İncelediğimiz bu eserde bulunan insan yüzlü hilal motifi Bursa Kent Müzesindeki $93 \mathrm{~cm}$ uzunluğundaki bir kılıcın üzerinde de görülmektedir. ${ }^{25}$

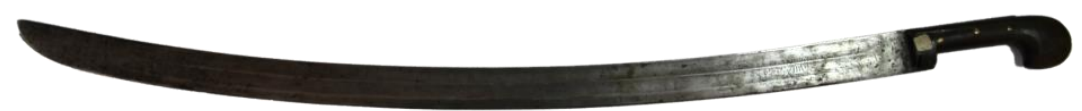

\footnotetext{
${ }^{24}$ Kelime "demir kesici” veya "demir işçisi” anlamına gelmektedir. https://tr.eferrit.com/eisenhower-soyadi-anlamive-koekeni/ (E.T. 17.02.2020)

${ }^{25}$ Dede, agt, s.50-52.
} 


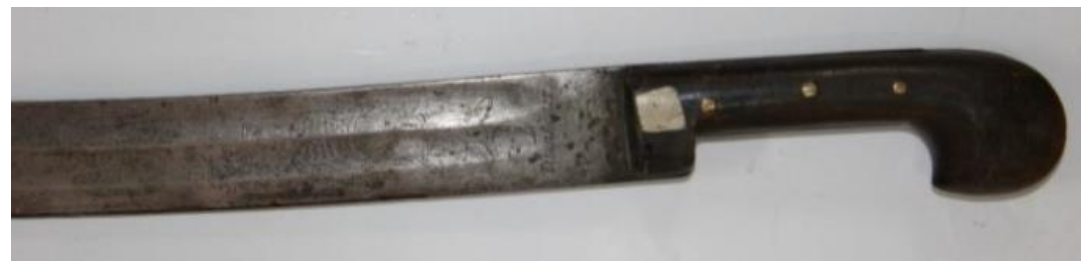

Fot. 49: Numarasız/1351 Envanter Numaralı Kılıç

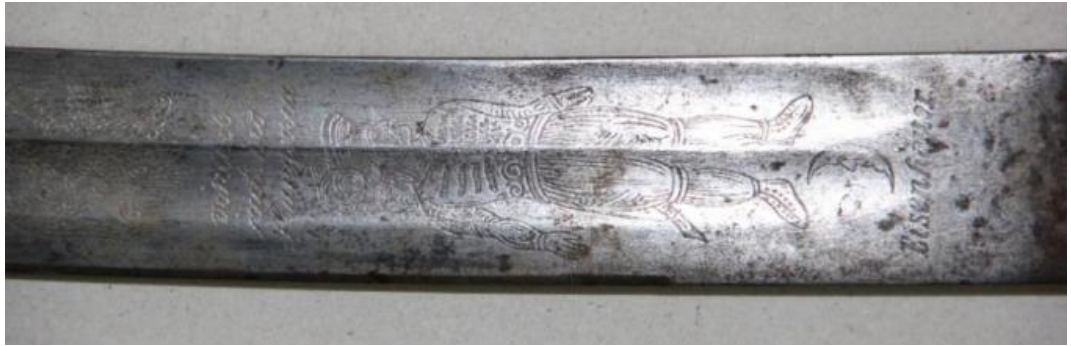

Fot. 50: Numarasız/1351 Envanter Numaralı Kılıç

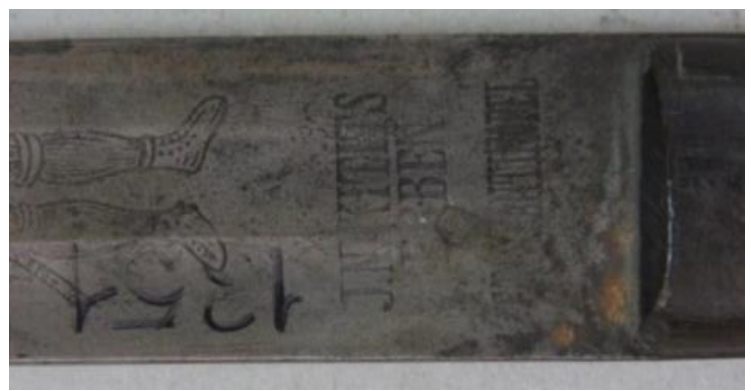

STUDTORY

1938

Volume 12

Issue 4

August

2020

Fot. 51: Numarasız/1351 Envanter Numaralı Kılıç

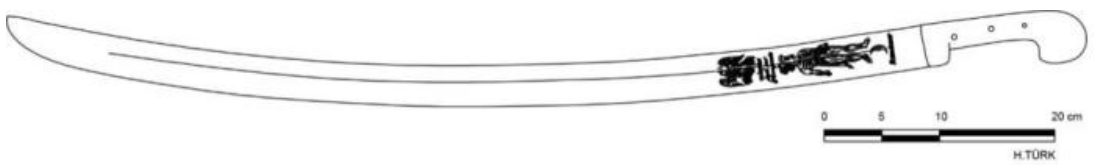

Çizim 51: Numarasız/1351 Envanter Numaralı Kılı̨̧

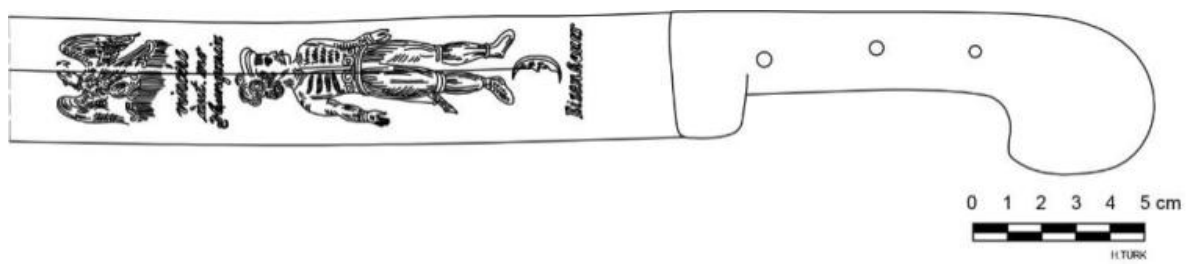

Çizim 52: Numarasız/1351 Envanter Numaralı Kılıç 


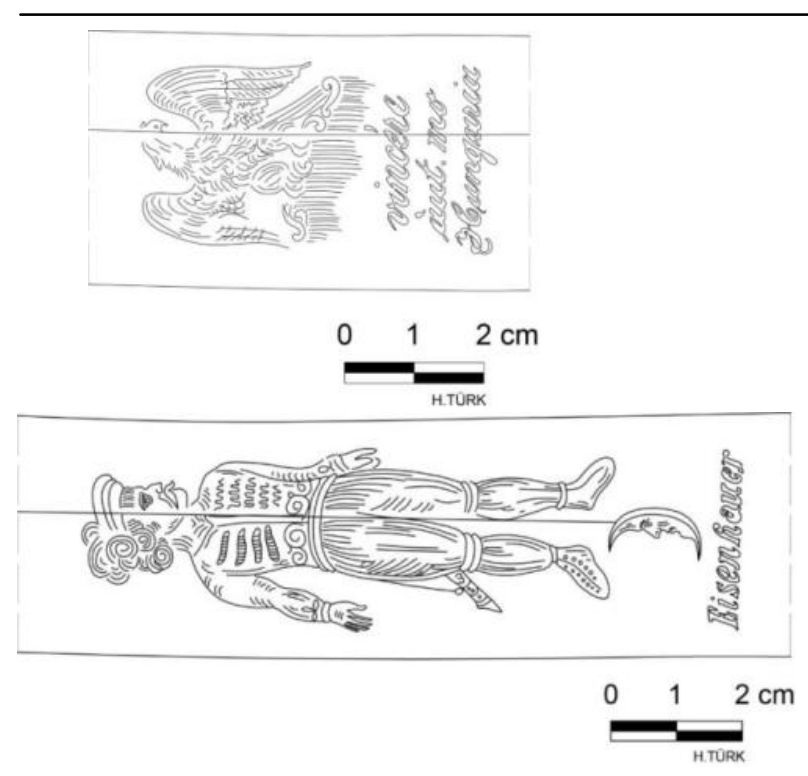

Eser No 20: 1556/883 envanter numarasına kayıtlı ucu hafif eğri kılıç 99 x 3,3 cm ölçülerindedir. Kabzası boynuzdan, namlusu demirden yapılan kılıcın namlusu çok paslandığ için üzerindeki süslemeler zorlukla görülebilmektedir. İki oluklu kılıcın yüzeyinde kazıma tekniğinde kabzadan uca doğru kıvrım dalların taşıdığı yapraklar ve yazı mevcuttur. Ancak k1lıcın üzerindeki yazılardan yalnızca 1919 tarihi okunabilmektedir (Fot. 52-53, Çizim 55). Bu kılıcın form açısından bir benzeri Bitlis Etnografya Müzesinde bulunmaktadır. ${ }^{26}$

Fot. 52: 1556/883 Envanter Numaralı K1lıç

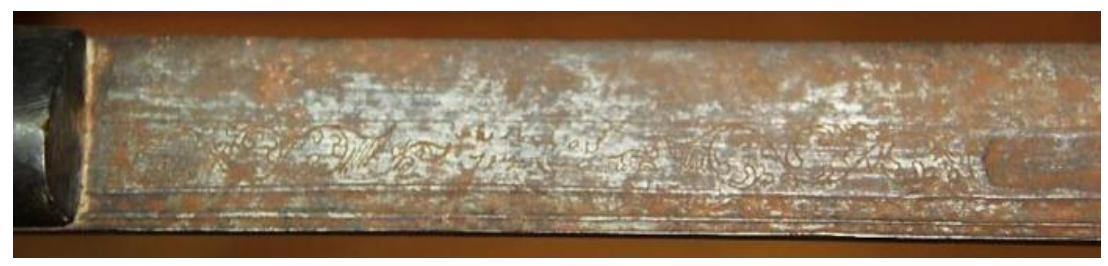

Fot. 53: 1556/883 Envanter Numaralı Kılıç

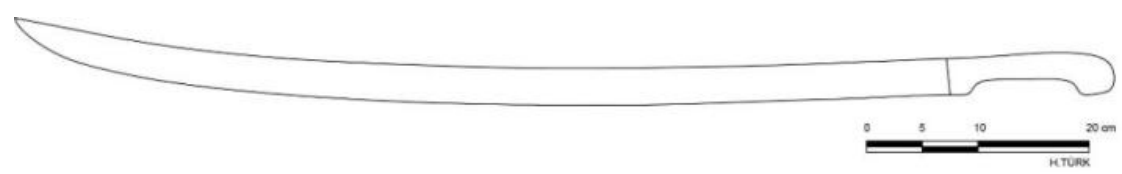

Çizim 55: 1556/883 Envanter Numaralı Kılıç

\footnotetext{
${ }^{26}$ Hacer Arslan Kalay, “Bitlis Etnografya Müzesi'nde Bulunan Osmanlı Dönemi Silahları”, Uluslararası Sosyal Araştırmalar Dergisi, C.11, S.56, Nisan 2018, s.186, Resim No:4.
}

\section{History Studies}


Koyunoğlu Şehir Müze ve Kütüphanesinde Bulunan Osmanlı Dönemi Kılıçları

Eser No 21: Müzede 1564 A/1102 envanter numarasına bahriye kılıcı olarak kaydedilen tören kılıc1 90 × $2 \mathrm{~cm}$ ölçülerindedir. Kabzası kemikten yapılarak kenarları yivlenmiş ve buraya altın tel sarılmıştır. Bu kısmın üzeri kabartma tekniğinde, aslan başı formunda bronzdan yapılmıştır. Aslanın ağzından çıkan metal sap, denizcilerin sembolü olan çapa işareti ve bunun üzerine yerleştirilen beş kollu yıldız motifiyle süslenmiş balçak kısmıyla birleşmektedir. Eserin namlusu demirden olup, süslemesizdir. Kını ise deri ve bronzdandır. Kının ağızlık ve orta kısmındaki bronz kaplama üzerinde birer adet bilezik ve yüzük mevcuttur. Çamurluğun yuvarlatılmış uç kısmında ise kazıma tekniğinde bitkisel süslemeler görülmektedir. Üzerinde herhangi bir tarih ibaresi bulunmayan eser, formu ve aslan başlı kabzasından yola çıkılarak 19. yüzyıl sonları, 20. yüzyıl başlarına tarihlendirilebilir (Fot. 54-56, Çizim 56-58). Kılıç, bu koleksiyonda yer alan iki eserle benzerlik içindedir (Fot. 57, 62).

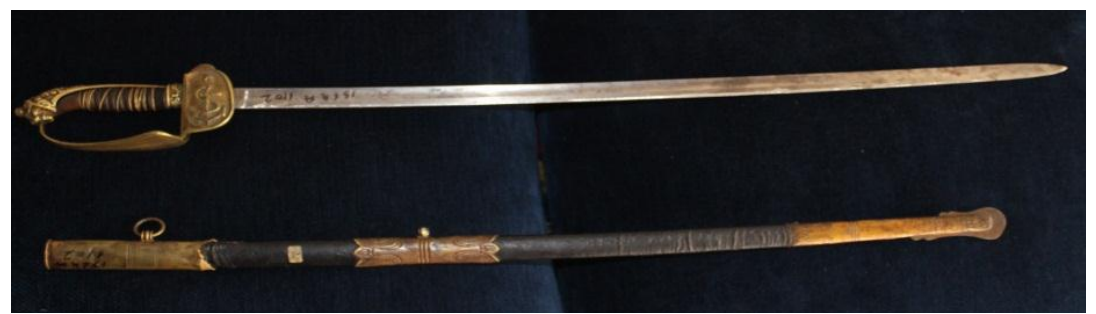

Fot. 54: 1564 A/1102 Envanter Numaralı Kılıç

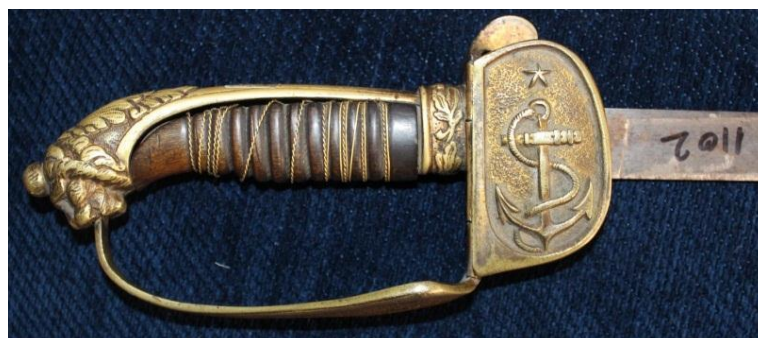

Fot. 55: 1564 A/1102 Envanter Numaralı Kılıç

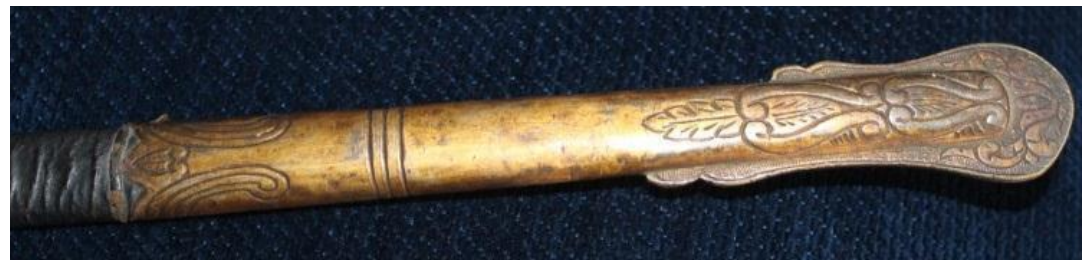

Fot. 56: 1564 A/1102 Envanter Numaralı Kılıç

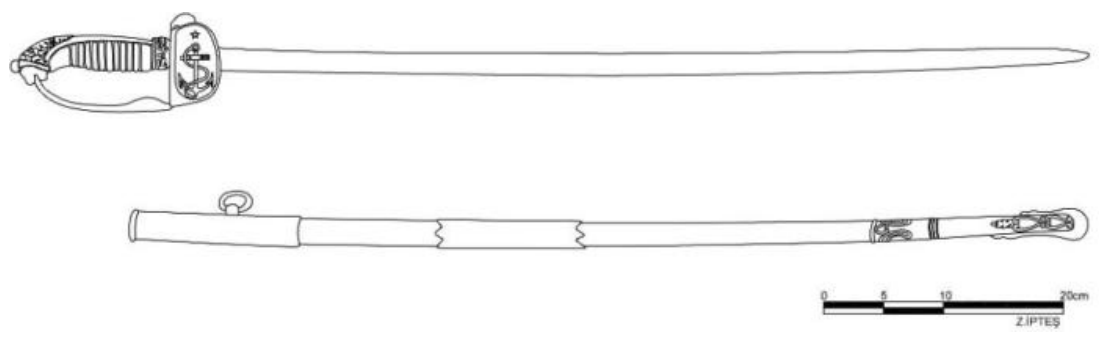

Çizim 56: 1564 A/1102 Envanter Numaralı Kılıç 


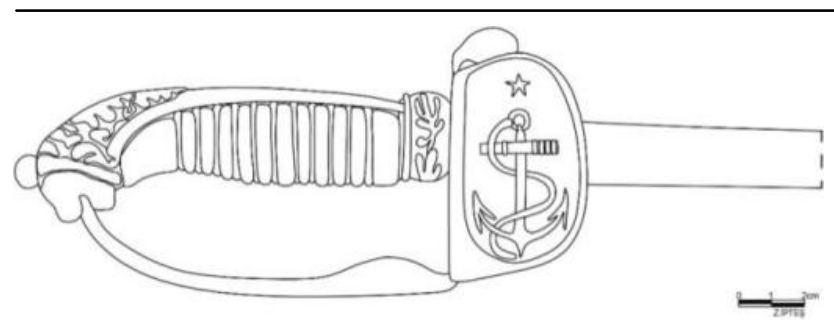

Çizim 57: 1564 A/1102 Envanter Numaralı Kılıç

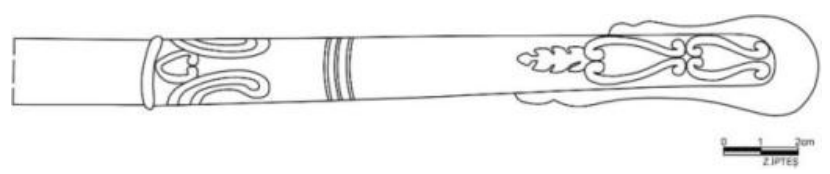

Çizim 58: 1564 A/1102 Envanter Numaralı Kılıç

Eser No 22: Müzede 1603/1083 envanter numarasına kaydedilen tören k1lıc1 85 x $2 \mathrm{~cm}$ ölçülerindedir. Kayıtlarda Osmanlı tipi subay kılıcı olarak geçen eser ve kını nikelaj kaplamalıdır. Altın telle sarılan kabzası, bronzdan yapılmış aslan başı şeklindeki topuzla tamamlanmıştır. Aslanın başı, yeleleri, gözleri, burnu ve dişleri oldukça ayrıntılı bir biçimde işlenmiştir. Kılıcın sap kısmı aslanın ağzından çıkarak balçağa bağlanmaktadır. Kabza kenarlardan içeriye doğru volüt şeklinde kıvrılmakta ve hem kabza hem de balçakta zemin oyma tekniğinde kıvrım dalların yer aldığı süslemeler görülmektedir. Ayrıca balçağın diğer yüzünde ay-yıldız motifine yer verilmiştir (Çizim 61). Kılıcın tek oluklu namlusunun üzerinde zemin oyma tekniğinde kıvrım dallar ve yaprakların bulunduğu bitkisel süslemeler göze çarpar. Kını süslemesiz olup, çamurluk kısmı yuvarlatılmıştır. Üzerinde iki adet bilezik ve birinde halka biçiminde yüzük bulunmaktadır. Eser formundan ve barok-rokoko tarzı bitkisel süslemelerinden yola çıkılarak 19. yüzyıl sonları, 20. yüzyıl başlarına tarihlendirilebilir (Fot. 57-61, Çizim 59-62). Formu ve aslan başlı kabzası bakımından koleksiyonumuzdaki iki örnekle benzeyen (Fot. 54, 62) bu kilıcın bir benzeri de Karaman Müzesinde mevcuttur. ${ }^{27}$

Volume 12

2020

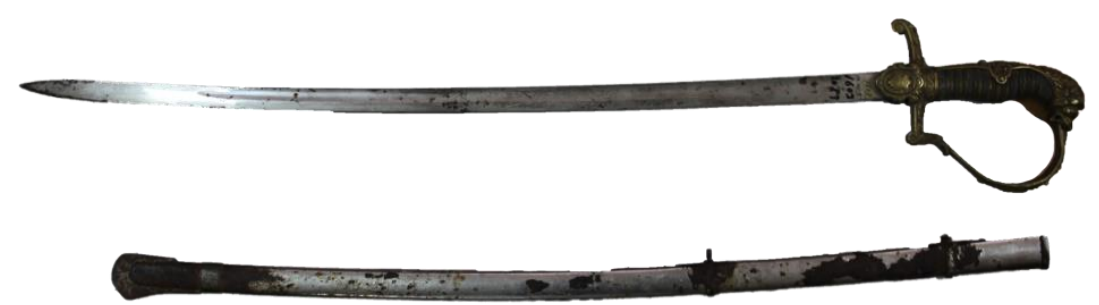

Fot. 57: 1603/1083 Envanter Numaralı Kılıç

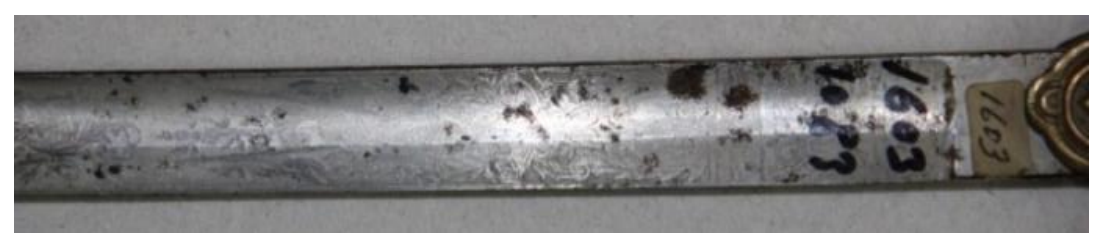

Fot. 58: 1603/1083 Envanter Numaralı Kılıç

${ }^{27}$ Atc1, agt, s.52, 154-155, Resim No:8-9.

History Studies 


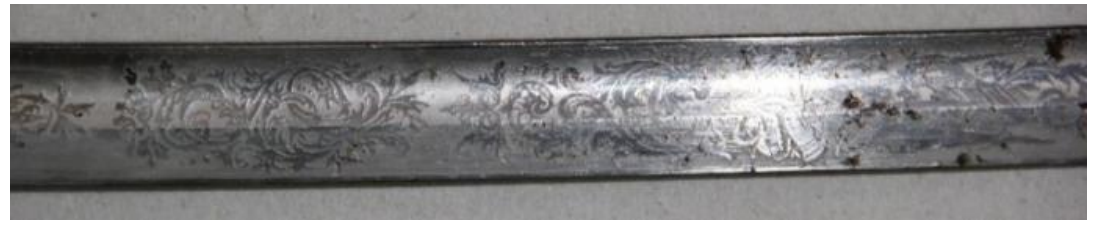

Fot. 59: 1603/1083 Envanter Numaralı K1lıcın Arka Yüzü

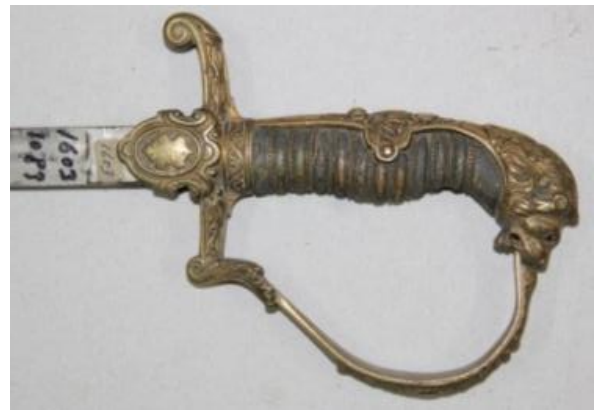

Fot. 60: 1603/1083 Envanter Numaralı Kılıç

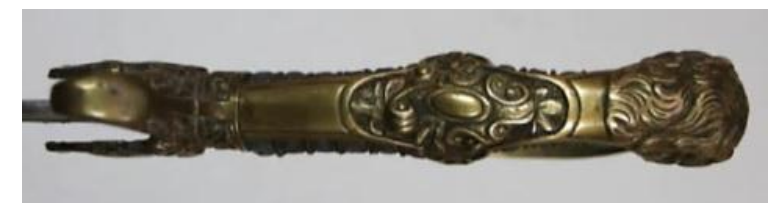

Fot. 61: 1603/1083 Envanter Numaralı Kılıç

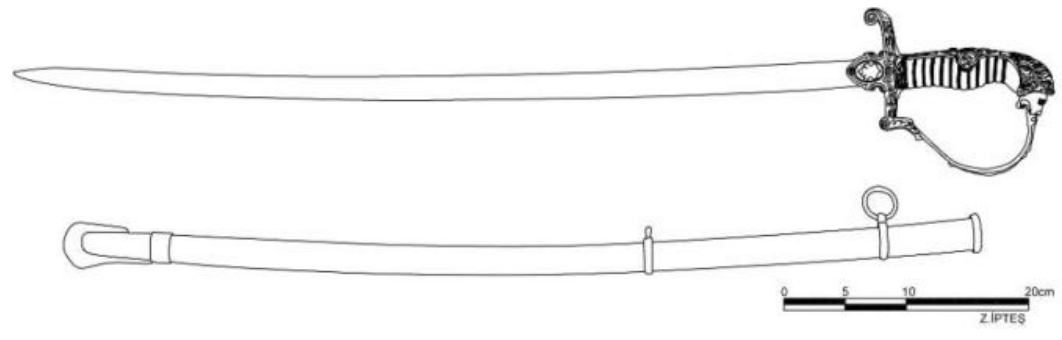

Çizim 59: 1603/1083 Envanter Numaralı Kılıç

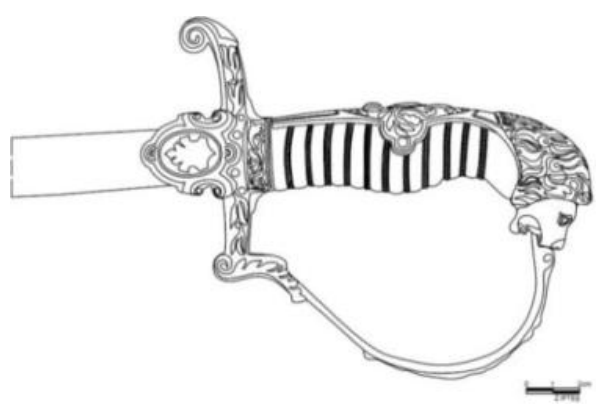

Çizim 60: 1603/1083 Envanter Numaralı Kılıç

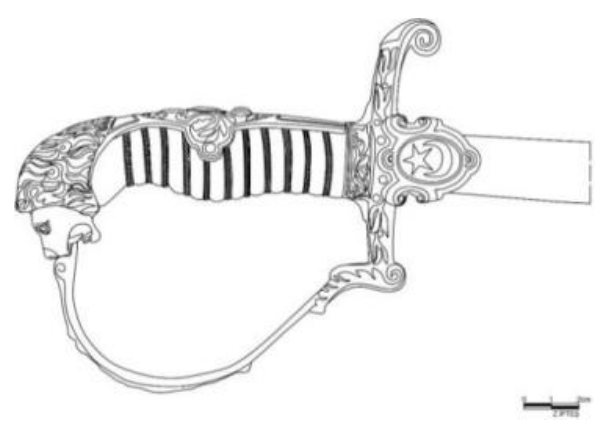

Çizim 61: 1603/1083 Envanter Numaralı Kılı̧̣

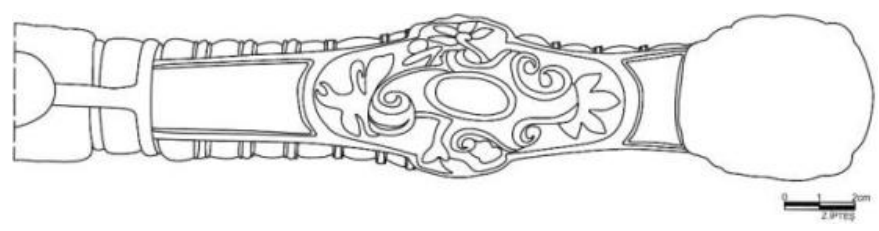

Çizim 62: 1603/1083 Envanter Numaralı Kılıç 
Eser No 23: Müzenin 1621/1089 envanter numarasına kayıtlı tören k1lıc1 97 × $2 \mathrm{~cm}$ ölçülerindedir. Fildişinden yapılan kabzasının üzeri yivlenerek buraya altın tel sarılmıştır. Kabzanın üzerinde bronzdan yapılmış kabartma biçimli aslan başı şeklinde bir topuz görülmektedir. Aslan başının tüm detaylarıyla yansıtıldığı dikkati çeker. Kılıcın balçak kısmı aslanın ağzından çıkan, üzeri zemin oyma tekniğinde bitkisel motiflerle süslenen, metal bir parçayla birleşmektedir. Kılıcın nikelaj kaplı namlusu zemin oyma tekniğinde ay-yıldız, sancak ve silah motifleriyle süslenmiştir. Boşluklarda kıvrım dallar ve yapraklara yer verilmiştir. Süsleme kılıcın uç kısmında palmet formunda olup, onunda ucu ay-yıldız motifiyle tamamlanmıştır. Eserin nikelaj kaplamalı süslemesiz kınının ucu yuvarlatılmıştır. Üzerinde iki adet bilezik ve metal halka bulunmaktadır. Formu ve süsleme özellikleri kılıcın 19. yüzyıl sonları, 20. yüzyıl başlarında yapıldığını göstermektedir (Fot. 62-65, Çizim 63-64). İncelediğimiz koleksiyonda bu k1lıcın benzeri olan iki eser mevcuttur (Fot. 54, 57).

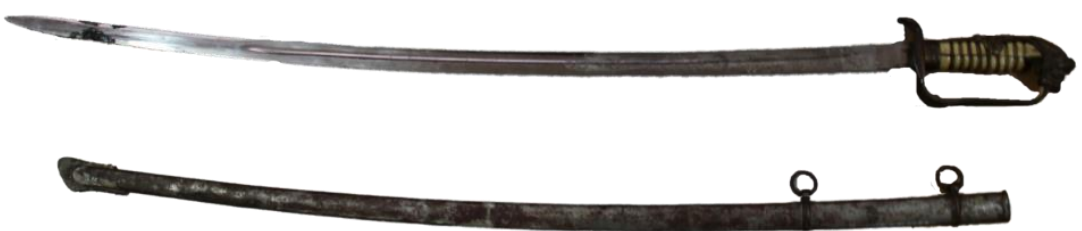

Fot. 62: 1621/1089 Envanter Numaralı Kılıç

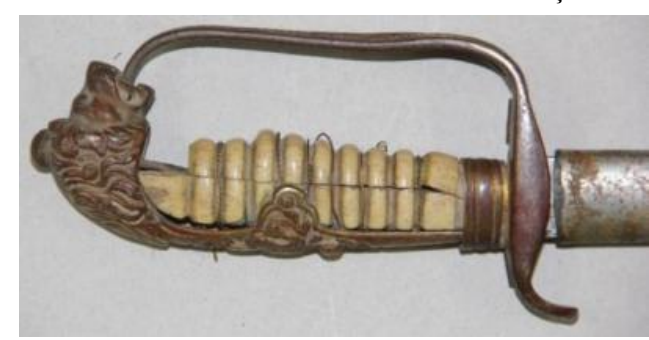

Fot. 63: 1621/1089 Envanter Numaralı Kılıç

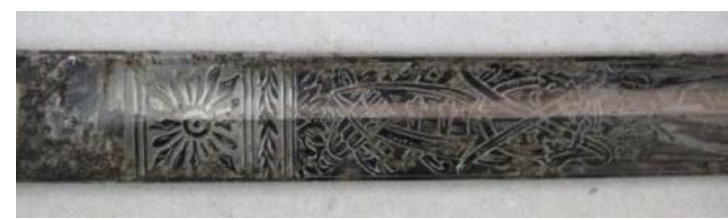

Fot. 64: 1621/1089 Envanter Numaralı Kılıç

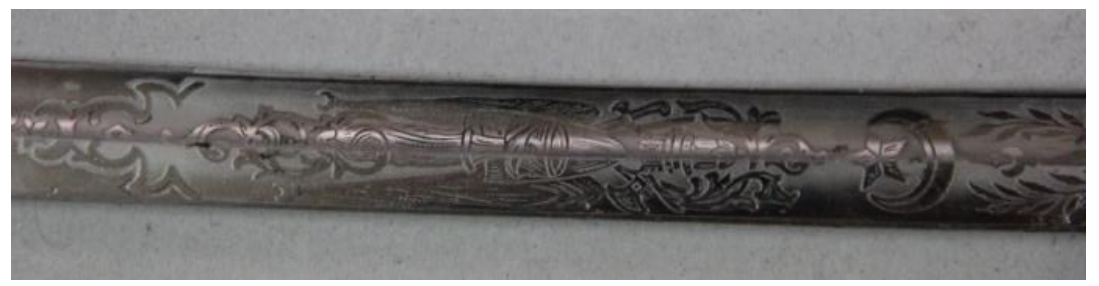

Fot. 65: 1621/1089 Envanter Numaralı Kılıç

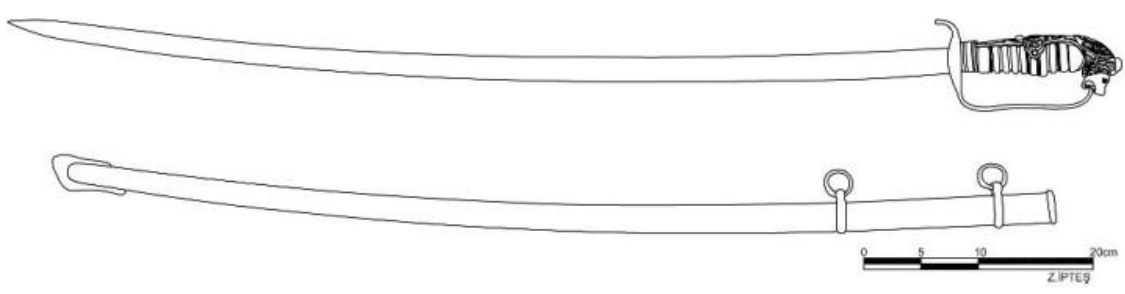

Çizim 63: 1621/1089 Envanter Numaralı Kılıç 


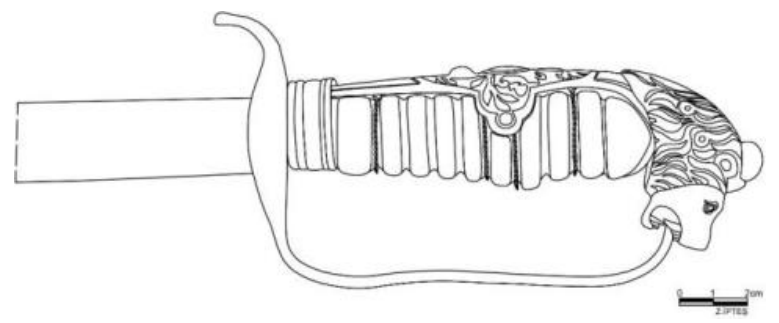

Çizim No 64: 1621/1089 Envanter Numaralı Kılıç

Eser No 24: 1598/784 envanter numaralı kısa kılıç 60 x 5 cm ölçülerindedir. Kabzası fildişinden, namlusu çeliktendir. Çift ağızlı kılıcın namlusu üç olukludur. Üzerinde herhangi bir tarih bulunmayan kılıcın kabzasında, büyük bölümü silinmekle birlikte, izleri kalan küçük bir süslemeli kısım mevcuttur. Burada altın kakma tekniğinde kıvrım dallar ve yapraklar göze çarpar. Bu süslemelerden ve formundan yola çıkılarak kılıcın 18-19. yüzyılda yapıldığ söylenebilir (Fot. 66-67, Çizim 65-66).

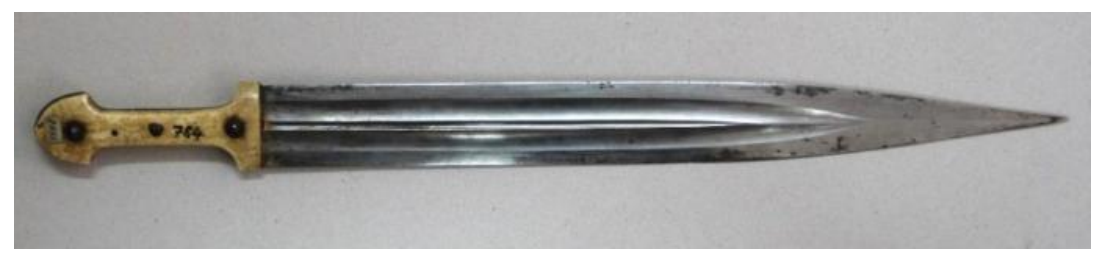

Fot. 66: 1598/784 Envanter Numaralı Kılıç

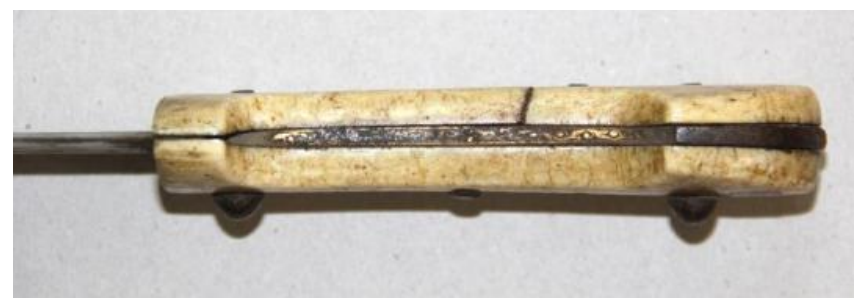

Volume 12

Issue 4

August

2020

Fot. 67: 1598/784 Envanter Numaralı Kılıç

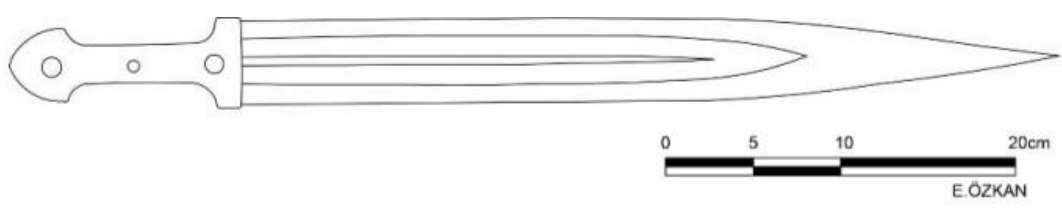

Çizim 65: 1598/784 Envanter Numaralı Kılıç

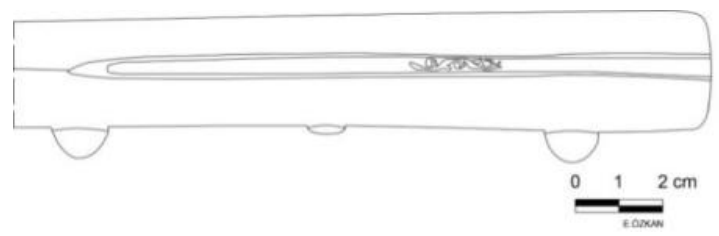

Çizim 66: 1598/784 Envanter Numaralı Kılıç 
Eser No 25: Müzede 1638/812 envanter numarasına kayıtlı kısa kılıç 54,4 x $5 \mathrm{~cm}$ ölçülerindedir. Ahşap üzerine gümüş kaplamalı kabzasının bir yüzü kıvrım dalların taşıdığı rumiler ve lale benzeri çiçeklerle bezenmiştir. Tek oluklu namlusu çelikten yapılmıştır. Oluk kısmının hemen üzerinde kenarları altınla tahrirlenen bir alanda altın kakma tekniğinde yazı ve süsleme görülmektedir. $\mathrm{Bu}$ kısımda talik hattıyla "Nasrun minallâhi ve fethun karîb Muhammed ve beşşiril-mû'minîn. ${ }^{28}$ Lâ seyfe illâ Zülfikâr, lâ fetâ illâ Ali. Sâhib-i Hasan Hilmi

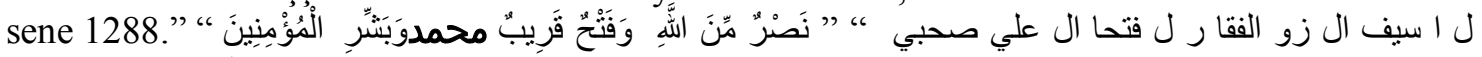
I YAM yazılıdır. Etrafı kıvrım dallar üzerinde yer alan barok tarzı yapraklarla süslenmiş̧tir. Kılıcın diğer yüzeyinde herhangi bir süsleme yer almamaktadır. Ahşap üzerine siyah deriyle kaplanan kının üzerindeki ağızlık ve çamurluk kısmı savatlı gümüş kaplamalıdır. Üzerinde yüzük ve halkası mevcuttur. Kının yalnızca bir yüzü kıvrım dallar üzerinde yer alan rumiler, çiçekler ve yapraklarla süslenmiştir. Envanter kaydında 17. yüzyıla tarihlendirilen k1lıcın, üzerindeki kitabeden 1288/1871-72 y1lında yapıldığı ve sahibinin de Hasan Hilmi isminde biri olduğu tespit edilmiştir (Fot. 68-69, Çizim 67-68).
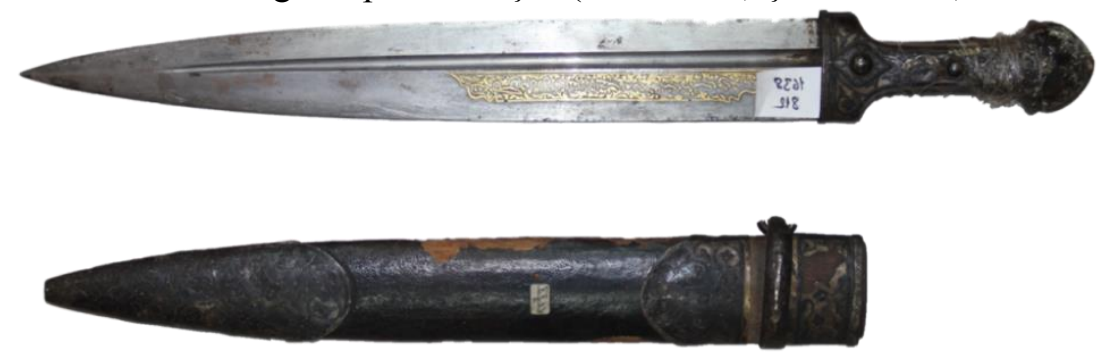

Fot. 68: 1638/812 Envanter Numaralı Kılıç

Volume 12

Issue 4

August

2020

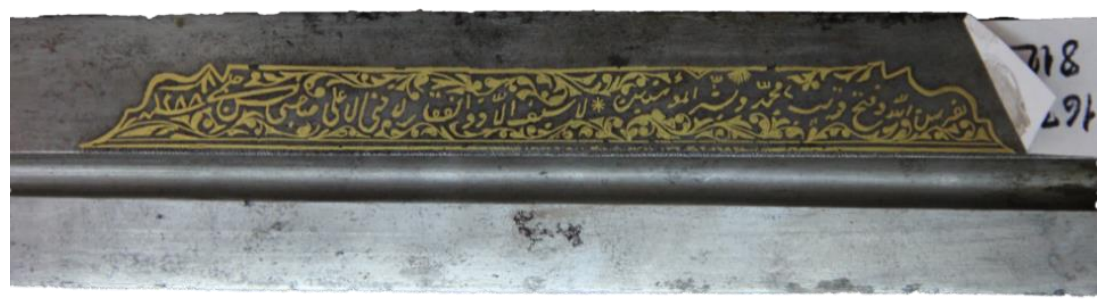

Fot. 69: 1638/812 Envanter Numaralı Kılıç

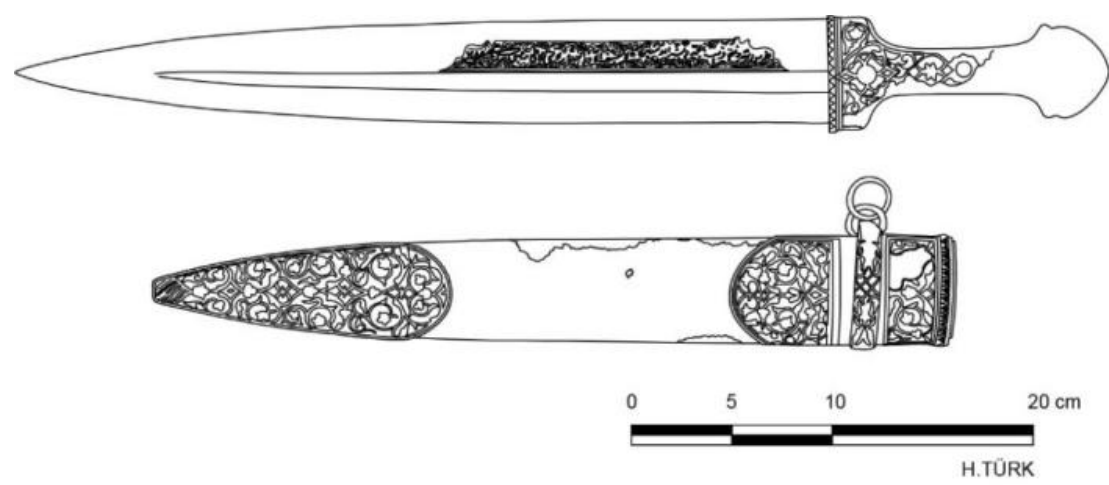

Çizim 67: 1638/812 Envanter Numaralı Kılıç

${ }^{28}$ Saf Sûresi 13. Ayet. Bu ayetin orijinal metninde Hz. Peygamberin ismi olan "Muhammed" geçmemektedir. Süleyman Ateş, Kur'ân-ı Kerîm ve Yüce Meâli, Ankara Tarihsiz, s.551. 


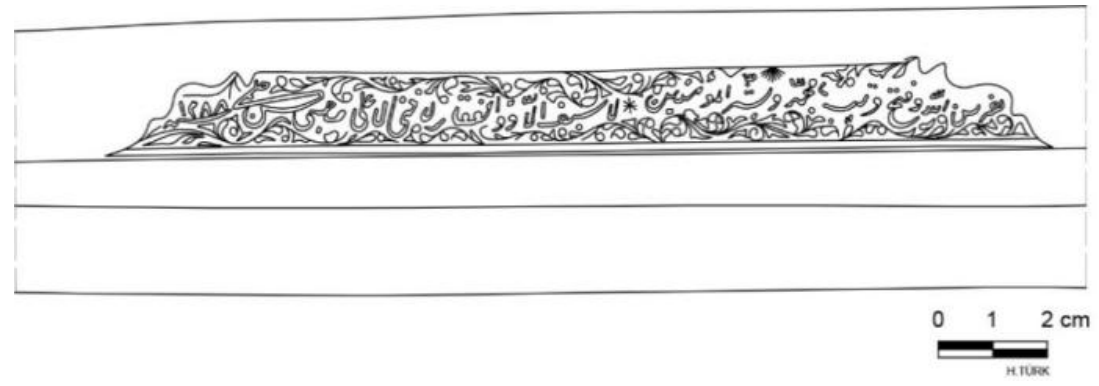

Çizim 68: 1638/812 Envanter Numaralı K1lıç

Eser No 26: 1632/2634 envanter numaralı kısa kılıç 46,5 x 4,5 cm ölçülerinde olup, ucu hafif eğiktir. Demir kabzalı, demir namlulu kılıcın kabzasının üzerine deri kaplanmıştır. Namlunun her iki yüzünde geometrik süslemeler mevcuttur. Bir yüzünde ise "Yemlihâ-

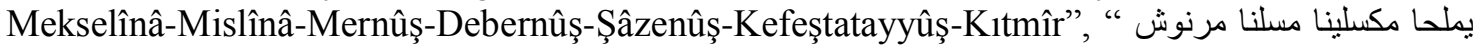
"دبرنوش شازنوش كفشطيوش=قطمير deriden olup üzeri süslemesizdir. Üzerinde tarih bulunmayan eser, formundan ve süslemelerinden yola çıkılarak 19. yüzyıla tarihlendirilebilir (Fot. 70-72, Çizim 69-70).
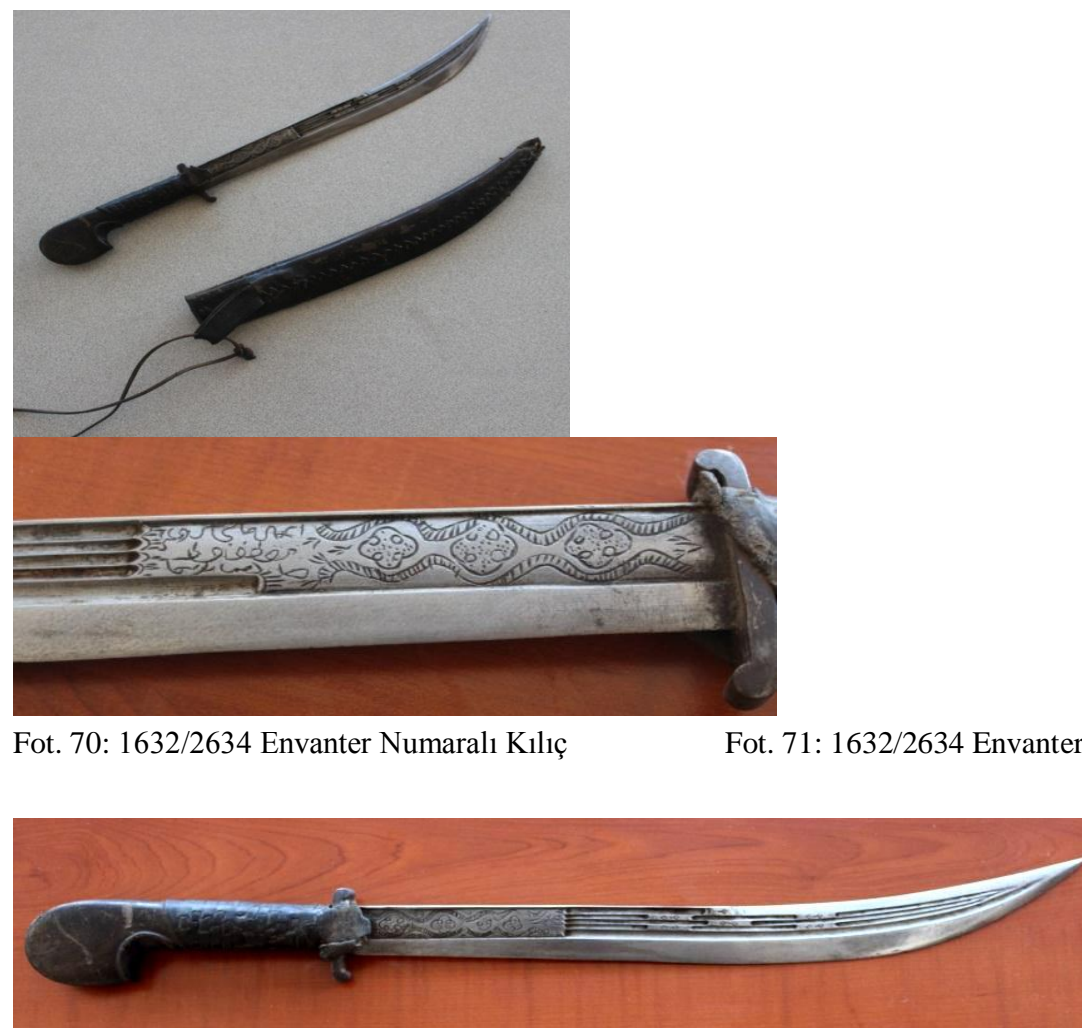

Fot. 72: 1632/2634 Envanter Numaralı Kılıç 


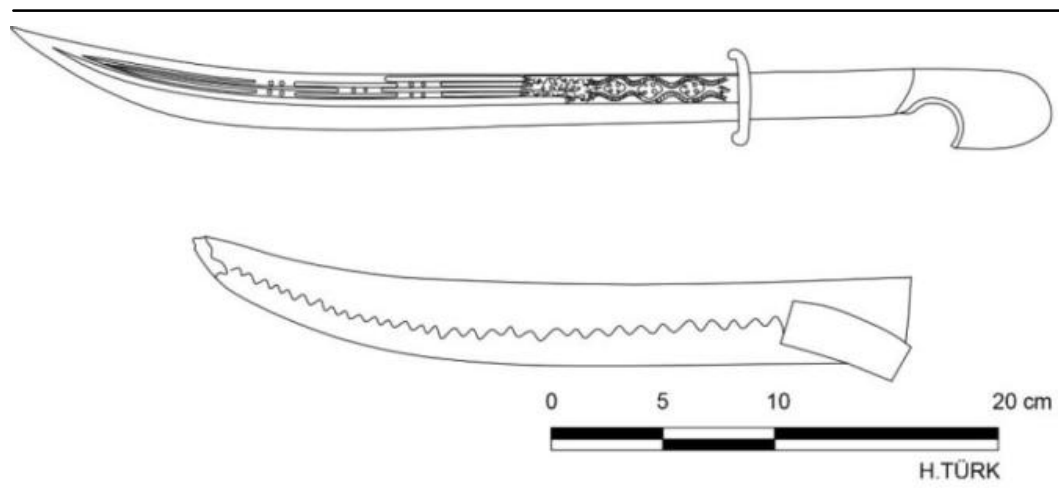

Çizim 69: 1632/2634 Envanter Numaralı Kılıç

HISTORY

STUDIES

1947

Volume 12

Issue 4

August

2020

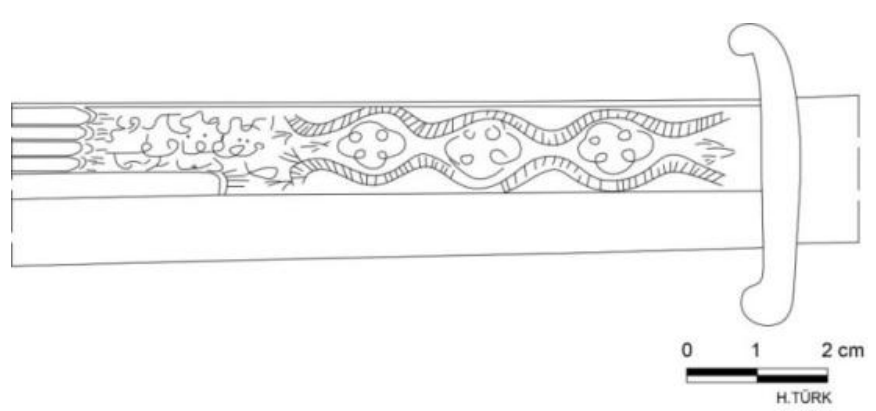

Çizim 70: 1632/2634 Envanter Numaralı Kılıç

Eser No 27: Müzede Numarasız/2643 envanterine kaydedilen kılıç sapı parçası $11,5 \mathrm{~cm}$ uzunluğundadır. Dikdörtgen formlu eserin bir ucu palmet formu şeklindedir. Metalden yapılan parça altın kakma tekniğiyle süslenmiştir. Eserin iki uzun yanında ikişer sıra altın cetvel arasında ince kıvrım dallar ve çizgiler yer almaktadır. Ortada ise üç dilimli palmet ve sekiz kollu yıldız görülmektedir. Bu parçanın 19. yüzyıla ait bir kılıcın parçası olduğu düşünülebilir (Fot. 73, Çizim 71).

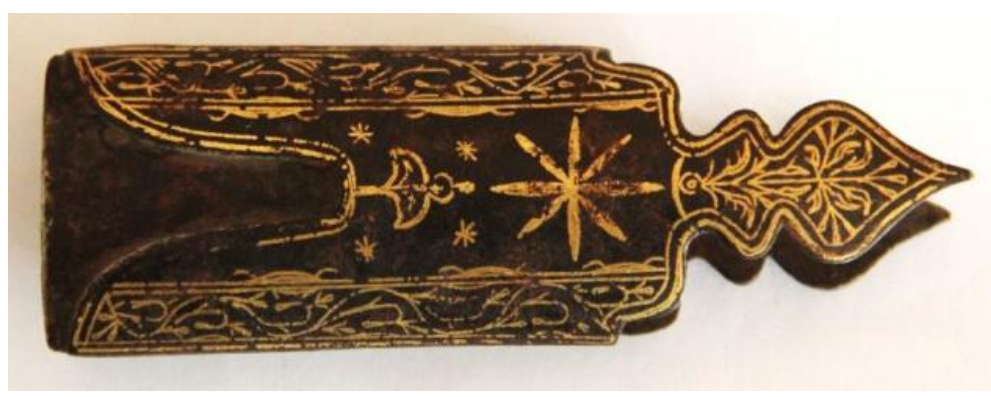

Fot. 73: Numarasız/2643 Envanter Numaralı Kılıç Sapı Parçası 


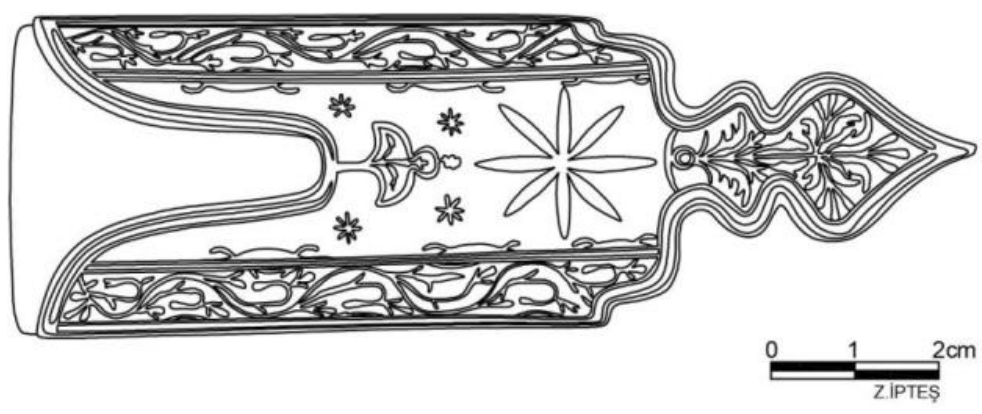

Çizim 71: Numarasız/2643 Envanter Numaralı Kılıç Sapı Parçası

\section{Değerlendirme}

"Koyunoğlu Şehir Müze ve Kütüphanesinde Bulunan Osmanlı Dönemi Kılıçları" adlı bu çalışmada, adı geçen müzede bulunan 26 adet k1lıç ve bir adet kılıç sapı tanıtılmıştır. Ele aldığımız kılıçlardan biri 17. yüzyıla (Eser No: 1), beşi 18-19. yüzyıla (Eser No: 2, 3, 10, 11, 24), 15'i 19. yüzyıla (Eser No: 4, 5, 6, 7, 8, 9, 12, 13, 14, 15, 16, 17, 18, 25, 26), dördü 19-20. yüzyıla (Eser No: 19, 21, 22, 23), biri 20. yüzyıl başlarına (Eser No: 20) ve kılıç sapı da 19. yüzyıla (Eser No: 27) tarihlenmektedir. Bu eserlerden beşi, üzerlerinde bulunan kayıtlardan yola çıkılarak kesin bir şekilde tarihlendirilirken (Fot. 8, 12, 17, 53, 69), diğerleri form ve bezeme kompozisyonundan yola çıkılarak yaklaşık olarak tarihlendirilmeye çalışılmıştır.

\subsection{Malzeme}

Müze bünyesinde incelenen k1lıçlarda farklı malzemelerin kullanıldığı görülmektedir. Kılıçların kabzalarında boynuz, kemik, ahşap ve demir gibi malzemelerle karşılaşılmaktadır. Beş kılıcın kabzaları ahşaptan yapılmıştır (Fot. 4, 5, 24, 29, 42). Ancak ahşap kabzaların bir kısmının yıprandığı gözlenmiş ve kabzalarda ahşap malzemenin diğer malzemelere nazaran daha dayanıksız olduğu tespit edilmiş̧ir. Üç eserin kabzası demirden (Fot. 2, 47, 72), altı eserin kabzası kemikten (Fot. 15, 18, 26, 41, 49, 55), üç eserin kabzası fildişinden (Fot. 35, 63, 67) dört eserin kabzası ise boynuzdandır (Fot. 6, 11, 31, 52). Bir eserin kabzası bronz (Fot. 40), bir eserin kabzası altın (Fot. 45) ve bir eserin kabzası ise gümüş (Fot. 68) kaplamadır. Eserlerin üçünün aslan figürlü kabzasında ince tel sarılmıştır (Fot. 55, 60, 63). İncelenen eserlerin 10 'unda balçak yer almaktadır. Balçakların malzeme ve süslemeleri genelde kabzayla benzer biçimdedir.

Kılıçların namlu kısımlarında en çok tercih edilen iki malzeme çelik ve demirdir. Ele alınan örneklerden 10'u çelikten, 14'ü ise demirden yapılmıştır. Ancak demirden yapılan eserlerin bir kısmının paslanarak daha çabuk bozulduğu gözlenmiştir. İki eserde ise farklı olarak nikelaj kullanılmıştır (Fot. 57, 62). Nikelaj kullanımı daha ziyade 19 ve 20. yüzyılda yapılan kılıçlarda karşımıza çıkmaktadır.

Kılıçların kınları ise çoğunlukla ahşap malzemeden yapılarak dış kısımları deriyle kaplanmıştır. Günümüze daha yakın zamanlarda yapılan eserlerden birkaçı ise nikel kaplamalıdır (Fot. 57, 62). 1565A/2682 envanter numaralı k1lıcın kını ise tamamen demirden yapılmıştır (Fot. 46).

İncelenen örneklerde kakma tekniğindeki süslemeler için gümüş (Fot. 8, 20) ve altın (Fot. 2, $3,12,13,27,28,67,69,73)$ malzemenin kullanıldığ tespit edilmiştir. Ayrıca bazı kılıçların kabza ve çamurluk kısımlarında da bu malzemelerin tercih edildiği görülmektedir (Fot. 32, 33, $36,44,45,68)$. 


\subsection{Teknik}

Çalışmamızda yer alan kılıçlarda teknik hususunu yapım ve süsleme tekniği olarak iki şekilde ele almak mümkündür. İncelenen örneklerin tamamının namlu kısımları dövme tekniğinde yapılmıştır. Malzeme olarak bir kısmında demir, bir kısmında çelik kullanılsa da, kılıçların hepsinin namlularının geleneksel yöntemlerle elde dövülerek yapıldığı görülmektedir. Ele alınan eserlerde yapım tekniği olarak dövme tekniğinin dışında herhangi bir teknikle karşılaşılmamıştır. Eserlerin kabzaları ise metal çivilerle namluya tutturulmuştur.

Kılıçlarda görülen bir diğer teknik ise süsleme tekniğidir. Konumuz kapsamında ele alınan örneklerin çoğunun kabza, balçak ve namlu kısımlarının süslemelerinde kazıma, zemin oyma, kabartma ve kakma olmak üzere farklı süsleme tekniklerinin uygulandığı saptanmıştır. Bazı kılıçların kabzaları tamamen süslemesiz bırakılmış, süslenenlerde ise teknik olarak kazıma, zemin oyma ve kabartma teknikleri tercih edilmiştir. Kabzaların ikisinde bitkisel kompozisyonların kazıma tekniğiyle yapıldığı görülmüştür (Fot. 40, 68, Çizim 41, 67). Üç örnekte tamamen kabartma tekniği kullanılarak kabzaya aslan başı formu kazandırılmıştır (Fot. 55, 60, 63, Çizim 57, 60, 64). Bir örneğin kabzasında ise farklı olarak kabartma bitkisel motiflerin ortalarına kabara çiviler yerleştirilmiştir (Fot. 10, 11, Çizim 11, 12). Eserlerin namlu kisımlarında kazıma (Fot. 16, 17), zemin oyma (Fot. 19, 23, 25, 50, 53, 59, 65, 71) ve kakma (Fot. 2, 3, 8, 12, 13, 20, 27, 28, 67, 69) teknikleri görülmektedir. Kılıç sapı parçası da yine kakma tekniğinde süslenmiştir (Fot. 73). Kakma tekniği, eserlerin motifleri üzerine açllan yivlere, malzeme olarak ince tel ya da ince varaklardan kesilmiş levhaların yerleştirilmesiyle elde edilmektedir. ${ }^{29}$ İncelediğimiz örneklerde bu teknik, gümüş ve altın madeni kullanılarak yapılmıştır.

İncelenen eserlerin tamamında kın mevcut değildir. Mevcut kınların çoğu ahşaptan yapılıp

Volume 12

Issue 4

August

2020 deriyle kaplanmış ve üzerinde süslemeye yer verilmemiştir. Ancak bir örnekte deriden ince şeritler kesilerek farklı bir süslemeye yer verilmiştir (Fot. 18, Çizim 20). Bazı kınların ağızlık ve çamurluk kısımlarına süslemeli madeni parçalar yerleştirilmiştir. Bu süslemelerin kazıma ve kabartma tekniklerinde yapıldığı gözlenmektedir. Bir kının çamurluk kısmında bitkisel motiflerin zemin oyma tekniğinde yapılmasına karşın hemen uç kısmının yılan-ejder formunda kabartma tekniğinde yapıldığı tespit edilmiştir (Fot. 32, 33). Baston görünümlü düz bir kılıcın ahşaptan yapılan kınının ucunda ise gümüş üzerine kazıma tekniğinde bitkisel süslemeler bulunmaktadır (Fot. 44).

\subsection{Form}

Türk kılıçlarının türleri ve biçimleri üzerine yapılmış müstakil bir çalışma bulunmamaktadır. Kılıçlara ilişkin kabul gören tipolojik bir çalışma bulunmadığından, kaynaklarda form açısından çok çeşitli bilgilerle karşılaşmak mümkündür. Ahat Ural Bikkul, Türk kılıçlarının taban (namlu) şekline göre düz, eğri, burma ve çatal kılıç olmak üzere dört farklı biçiminden bahseder. ${ }^{30}$ Nebi Bozkurt, kılıçların genel olarak düz ve eğri olmak üzere ikiye ayrıldığını, düz olanların iki, eğri olanların bir tarafının keskin olduğunu belirtmektedir. ${ }^{31}$ Hilmi Aydın ise kılıç türlerinden bahsederken, kılıçla aynı işi gördüğünü söyleyerek, hançer, kama ve yatağan hakkında kısa bilgiler vermektedir. ${ }^{32}$ Bazı kaynaklarda kılıç ve diğer ateşsiz silahların ölçülerinden yola çıkılarak isimlendirildikleri de görülmektedir. Bu doğrultuda 36-50

\footnotetext{
${ }^{29}$ Tülin Çoruhlu, Osmanlı Koruyucu Silahlarında Süslemeler ve Teknikler (Askeri Müzeden Örnekler İle), (İstanbul Üniversitesi Sosyal Bilimler Enstitüsü, Yayınlanmamış Doktora Tezi), İstanbul 1995, s.20.

${ }^{30}$ Bikkul, agm, s.23-24.

${ }^{31}$ Bozkurt, agmd, s.406.

${ }^{32}$ Aydin, age, s.49.
} 
cm uzunluğa sahip olanlar kısa kılıç, bunun üzerindeki ölçülere sahip olanlar kılıç olarak nitelendirilmektedir. ${ }^{33}$ Araştırmamız sırasında incelenen eserlerin uzunlukları $113 \mathrm{~cm}$ ile 46,5 $\mathrm{cm}$ arasında değişmektedir. Örneklerimizden biri ise kılıç sapı parçası olup, $11,5 \mathrm{~cm}$ ölçülerindedir. İncelediğimiz koleksiyondaki kılıçların birkaç farklı formda yapıldıkları görülmektedir. Çalı̧̧mamızda bunlar "yatağan”, "pala”, "süvari (sabre) kılıcı", "düz kılıç”, "ucu hafif eğri kılıç", "tören kılıcı" ve "kısa kılıç" şeklinde gruplandırılmıştır. Ele alınan örneklerden dokuzu "yatağan" (Fot. 1, 4, 5, 6, 9, 14, 18, 22, 24), biri "pala" (Fot. 26), beşi "süvari (sabre) k1lıcı" (Fot. 29, 30, 34, 38, 41), üçü "düz k1lıç" (Fot. 42, 43, 46), ikisi "ucu hafif eğri k1lıç" (Fot. 48, 52), üçü "tören k1lıcı" (Fot. 54, 57, 62), üçü "kısa k1lıç" (Fot. 66, 68, 70) ve biri ise "kılıç sapı parçası" (Fot. 73) olarak karşımıza çıkmaktadır. Bu kılıç sapı dikdörtgen şeklinde olup, uç kısmı palmet formunda yapılmıştır.

Türklerle özdeşleşen silahlardan biri olan yatağan, 16. yüzyılın ikinci yarısında görülmeye başlar ve formu hemen hemen hiç değişmeden 19. yüzyıl sonlarına kadar kullanılır. ${ }^{34}$ Yatağanların en belirgin özellikleri, kemik veya fildişinden yapılan kabzalarının iki büyük kulak şeklinde yanlara doğru açılmasıdır. Kısa ve hafif eğri olan namlusunun iç kenarı keskin ve ucu sivridir. ${ }^{35}$ Ele aldığımız yatağanların formları da genel olarak bu tarife uygun olmakla birlikte bir kısmının kabzası iki kulaklı (Fot. 5, 6, 10, 15) bir kısmı ise düzdür (Fot. 2, 4, 18, 24). Bir örneğin kabzası ise günümüze ulaşamamıştır (Fot. 22). İncelediğimiz 1634/781 envanter numaralı yatağan (Fot. 9-13) Kırıkkale Müzesinde 83 envanter numarasına kayıtlı bir yatağanla formu, ölçüleri ve süslemeleri bakımından birebir benzerlik içindedir. ${ }^{36} \mathrm{Bu}$ yatağan 1238/1822-23 tarihli olup, bizim eserimizden yalnızca bir yıl sonra yapılmıştır. Bu bakımdan aynı üretim merkezinde ve aynı ustanın eliyle yapılıp farklı şehirlere ulaşmış olması mümkündür.

18. yüzyılda ortaya çıktığı bilinen palalar ${ }^{37}$, balçaktan uca doğru genişleyerek, ucu sivri ve kavisli bir görünüme sahiptirler. Karaman Müzesindeki bir eserle form açısından benzerlikleri bulunan $^{38}$ ve kesin yapım tarihi bilinmemekle birlikte 18-19. yüzyıla tarihlendirdiğimiz bir eserimiz pala formundadır (Fot. 26).

1806 yılında Nizam-1 Cedid 1slahatları neticesinde orduda kullanılan eğri formlu Türk kılıçlarının kaldırılarak, yerine batı etkili tek tip kılıçların üretildiği görülmüştür. ${ }^{39}$ Bu kılıçların daha çok törenlerde kullanıldıkları söylenebilir. Çalışmamızda buna örnek verebileceğimiz üç kılıcın (Fot. 54, 57, 62) form ve süslemeleri bakımından benzeri Karaman Müzesinde ${ }^{40}$ görülmektedir.

Bahattin Ögel Macar kılıçları hakkında bilgi verirken, tek ağızlı ve uca doğru hafif eğri olduklarını bildirmektedir. ${ }^{41}$ Çalışmamızda yer alan Numarasız/1351 envanter numaralı Macar yapımı kılıç da bu tanımlamaya uygun olarak ucu hafif eğri bir biçimde yapılmıştır (Fot. 48).

${ }^{33}$ Gülşah Altunkaynak, Erzurum ve Kars Müzelerinde Bulunan Urartu Dönemi Öncesine Ait Metal Silahlar, (Atatürk Üniversitesi Sosyal Bilimler Enstitüsü, Yayınlanmamış Doktora Tezi), Erzurum 2016, s.119.

${ }^{34}$ Aydin, age, s.49.

${ }^{35}$ Eralp, age, s.69-71; Aydın, age, s.49.

${ }_{36}^{36}$ Aydın, agt, s.73-74, Resim No: 51-52, s.335.

${ }^{37}$ Sultan Güneşli, Diyarbakır Arkeoloji Müzesinde Bulunan Osmanlı Dönemi Silahları, (Yüzüncü Yı1 Üniversitesi Sosyal Bilimler Enstitüsü, Yayınlanmamış Yüksek Lisans Tezi), Van 2008, s.24.

${ }^{38}$ Atc1, agt, s.57, 158, Resim No:16.

${ }^{39}$ Eralp, age, s.66.

${ }^{40}$ Atc1, agt, s.52, 154-155, Resim No:8-9.

${ }^{41}$ Bahaeddin Ögel, "Türk Kılıcının Menşe ve Tekâmülü Hakkında”, Ankara Üniversitesi Dil ve Tarih-Coğrafya Fakültesi Dergisi, C.6, S.5, Ankara 1948, s.455. 
Bunun dışında 1556/883 envanter numaralı kılıcın formu da aynıdır (Fot. 52). Her iki kılıcın form açısından benzeri Bitlis Etnografya Müzesinde yer almaktadır. ${ }^{42}$

Giriş bölümünde bahsettiğimiz üzere k1liçlar genel olarak kabza, balçak, namlu ve kın bölümlerinden oluşmaktadır. İncelediğimiz eserler içinde bir kılıcın kabzası yok olmuştur (Fot. 22). Mevcut kabzaların çoğu namlunun ters yönüne bakar vasiyette yuvarlak bir topuz bölümüne sahiptir. Elin korunmasında önemli olan balçağın yatağanlarda bulunmadığı gözlenmiştir. Balçak, ele aldığımız örneklerde pala, süvari (sabre) kılıçları ve tören kılıçlarında karşımıza çıkmaktadır. Biçim olarak kenarlardan namluya doğru kıvrılan bir görünümdedirler. Kılıçların namlu kısımlarında 1-2-3 adet kan oluğu yer almaktadır. Bütün kılıçların kınları bulunmamaktadır ancak mevcut kınlarda ağızlık, çamurluk ve bilezik kısımları görülmektedir.

\subsection{Süsleme}

Araştırmamamız kapsamında yer alan kılıçların bir kısmı tamamen süslemesiz olarak bırakılmıştır. Süslemeli kılıçlarda ise kabza, balçak, namlu ve kın kısımlarında süslemelere yer verilmiştir. Bazı örneklerde bahsettiğimiz kısımların tamamı, bazılarında ise bunlardan bir kısmı bezenmiştir. Süsleme tekniği olarak yukarıda bahsettiğimiz üzere, kazıma, zemin oyma, kabartma ve kakma teknikleri kullanılmıştır. Kılıçlarda bezeme kompozisyonu olarak geometrik, figürlü ve bitkisel süsleme ile yazı görülmektedir. Sekiz örnekte görülen geometrik süslemede ay-yıldız motifleri, daire formları ve "C" kıvrımlarıyla karşılaşılmaktadır. Bu eserlerden ikisinin namlusunda (Fot. 57, 65), bir eserin balçağında (Çizim 61), bir eserin kınında (Fot. 37) ay-yıldız motifi, dört eserin namlusunda helezonik biçimli daire motifleri (Fot. 3, 7, 21, 23), bir eserin namlusunda daireler içinde yıldız motifleri (Fot. 21, Çizim 23), bir eserin namlusunda (Fot. 25) ve bir eserin kabzasında (Fot. 45) "C" kıvrımlarına yer verilmiştir. Kılıçlarda figürlü süslemelerde görülmektedir. Eserlerin üçünün kabzası aslan başı formunda süslenmiş (Fot. 55, 60, 63, Çizim 57, 60, 64), bir eserde insan ve kartal (Fot. 50, Çizim 52, 53, 54), bir eserde ise yılan-ejder (Fot. 32, 33, Çizim 35) motiflerine rastlanmıştır. Aslan başlı kabzaya Karaman Müzesinde ${ }^{43}$ de rastlamak mümkündür. Bitkisel süslemede kıvrım dalların taşıdığ çiçek ve yapraklar (Fot. 2, 19, 39, 40, 44), selvi motifleri (Fot. 21, Çizim 24), barokrokoko tarzı bitkiler (Fot. 25, 53, 59, 64, 65, 69, 73) resmedilmiştir. Nesneli bezemeye örnek olarak bir eserin kabzasında denizcilerin sıklıkla kullandığı çapa işareti gösterilebilir (Fot. 55).

Eserlerde yazı olarak Arap alfabesi ve Latin alfabesinin kullanıldığı görülmektedir. Kılıçlarda yer alan yazılar kazıma ve kakma tekniğinde yazılmış, beş örnekte açık biçimde tarih belirtilmiş (Fot. 8, 12, 17, 53, 69) ve tarih ibaresi de rakamlarla yazılmıştır. Arap alfabeli metinlerde fetihle ilişkili olarak Saff Suresi 13. Ayeti, Hz. Ali ve Ashâb-1 Kehf isimleri, "tevekkeltü al'Allah" ve "MâşâAllah" ibareleri ve Osmanlıca metinli şiirlerle karşılaşılmaktadır. Yazıların bir kısmı kartuş içine alınmış (Fot. 12, 16, 20, 27, 28, 69), bir örnekte ise yazılar tuğra formunda yazılmıştır (Fot. 8). Bir eserde kılıcı yapan Hasan ustanın (Fot. 12), üç eserde ise kılıcın sahibi olan Konyava-yi Osman (Fot. 2), Mustafa (Fot. 12) ve Hasan Hilmi (Fot. 69) isimlerine yer verilmiştir. İki eser üzerinde damga bulunmaktadır, ancak bunları okumak mümkün olmamıştır (Fot. 24, 38). Sülüs, nesih ve talik hattının tercih edildiği bu yazıların sanatsal açıdan zayıf olduğunu söylemek mümkündür. Latin alfabeli birkaç örnekte ise kılıcın nerede yapıldığını bildiren yazılara rastlanmıştır (Fot. 43, 50, 51).

\footnotetext{
${ }^{42}$ Kalay, agm, s.186, Resim No:4.

${ }^{43}$ Atc1, agt, s.52, 154-155, Resim No:8-9.
} 


\section{Sonuç}

$\mathrm{Bu}$ araştırmada Koyunoğlu Şehir Müze ve Kütüphanesinde bulunan Osmanlı dönemine ait 26 adet kılıç ve bir adet kılıç sapı incelenmiştir. Türk sanatında oldukça çeşitli malzemeler ve formlarla yapılmış örnekleri bulunan kılıçlar bir saldırı silahı olmasının yanında tarihsel, kültürel ve sanatsal açıdan da sembolleşerek öne çıkmış eserlerdir.

Müzede yer alan kılıçların beşinin üzerindeki tarihten, diğerlerinin bezeme kompozisyonlarından ve kıyaslamalar neticesinde elde edilen bilgilerden yola çıkılarak, 17-20. yüzyıllar arasında yapılmış geç dönem Osmanlı eserleri oldukları sonucuna varılmıştır. Eserlerin malzeme, teknik, form ve süsleme bakımından dönemine uygun özellikler taşıdığ tespit edilmiştir. Kılıçların namlularının demir, çelik ve nikelden, kabzalarının fildişi, kemik, boynuz, ahşap, demir, bronz, gümüş ve altından, balçak kısımlarının ise gümüş ve bronzdan yapıldığı görülmektedir. Kınların ise büyük bölümü ahşaptan yapılarak deriyle kaplanmıştır. Nikel ve demirden yapılan iki örneğe de rastlanmıştır.

Eserlerin kabza, balçak, namlu ve kınlarında süslemeye yer verilmiştir. Buralarda geometrik, figürlü, barok-rokoko tarzı bitkisel motifler ve yazının görüldügü süslemeler mevcuttur. Kılıçların ve kınların süslemelerinde kazıma, zemin oyma, kabartma ve kakma teknikleri kullanılmıştır. Bu tekniklerin genelde kabza ve namlu kısımlarında yoğunlaştığı görülür. Kılıçlar genel olarak form, teknik, bezeme kompozisyonları ve üzerlerindeki yazı açısından değerlendirildiğinde zengin veriler sunarken, bazı örneklerde işçilik kalitesinin biraz düşük olduğu ve süslemeye yer verilmediği gözlenmektedir.

Çalışmamız neticesinde; Koyunoğlu Müzesinde bulunan ve henüz yayınlarda yer verilmeyen bir gurup kılıç, ayrıntılı bir biçimde incelenerek bilim dünyasına tanıtılmaya çalışılmıştır. Bu vesileyle Konya'da bulunan örneklerin bir kısmı gün yüzüne çıkarılmıştır.

\section{Kaynakça}

ALTUNKAYNAK, Gülşah, Erzurum ve Kars Müzelerinde Bulunan Urartu Dönemi Öncesine Ait Metal Silahlar, (Atatürk Üniversitesi Sosyal Bilimler Enstitüsü, Yayınlanmamış Doktora Tezi), Erzurum 2016.

ATCI, İsmail, Karaman Müzesi Etnografik Seksiyonda Sergilenen Ateşli ve Ateşsiz Silahlar, (Selçuk Üniversitesi Sosyal Bilimler Enstitüsü, Yayınlanmamış Yüksek Lisans Tezi), Konya 2014.

ATEŞ, Süleyman, Kur'ân-ı Kerîm ve Yüce Meâli, Ankara Tarihsiz.

AYDIN, Hilmi, Sultanların Silahlarl, İstanbul 2007.

AYDIN, Cemile, Kırıkkale MKEK Silah Müzesinde Bulunan Osmanlı Dönemi Silahları, (Gazi Üniversitesi Sosyal Bilimler Enstitüsü, Yayınlanmamış Yüksek Lisans Tezi), Ankara 2009.

BİKKUL, Ahat Ural, “Topkapı Sarayı Müzesindeki Türk Kılıçları Üzerinde Bir İnceleme”, Türk Etnografya Dergisi, S.IV, Ankara 1962, s.20-28.

BOZKURT, Nebi, "Kılıç", Türkiye Diyanet Vakfi İslam Ansiklopedisi, C.25, Ankara 2002, s.405-408.

ÇOLAK, Mihrican, "Türkçenin Söz Varlığında "K1lıç", Uluslararası Türkçe Edebiyat Kültür Eğitim Dergisi, S.7/4, 2018, s.2154-2188. 
ÇORUHLU, Tülin, Osmanlı Koruyucu Silahlarında Süslemeler ve Teknikler (Askeri Müzeden Örnekler Ille), (İstanbul Üniversitesi Sosyal Bilimler Enstitüsü, Yayınlanmamış Doktora Tezi), İstanbul 1995.

ÇORUHLU, Tülin, "Tasvirlere Göre Selçuklu Silahları ve Bu Silahların Osmanlılardaki Devamı", VI. Millî Selçuklu Kültür ve Medeniyeti Semineri Bildirileri, 16-17 Mayls 1996, Konya 1997, s.49-68.

DEDE, Gizem, Bursa Kent Müzesi Çengiç Beylikleri’ne Ait Silah Koleksiyonu, (Süleyman Demirel Üniversitesi Sosyal Bilimler Enstitüsü, Yayınlanmamış Yüksek Lisans Tezi), Isparta 2018.

ERALP, T. Nejat, Tarih Boyunca Türk Toplumunda Silâh Kavramı ve Osmanlı Imparatorluğunda Kullanılan Silâhlar, Ankara 1993.

GÜNEŞLİ, Sultan, Diyarbakır Arkeoloji Müzesinde Bulunan Osmanlı Dönemi Silahlarl, (Yüzüncü Yı1 Üniversitesi Sosyal Bilimler Enstitüsü, Yayınlanmamış Yüksek Lisans Tezi), Van 2008.

KALAY, Hacer Arslan, "Bitlis Etnografya Müzesi’nde Bulunan Osmanlı Dönemi Silahları”, Uluslararası Sosyal Araştırmalar Dergisi, C.11, S.56, Nisan 2018, s.183-192.

ÖZCAN, Abdülkadir, "Kılıı̧ Alayı", Türkiye Diyanet Vakfi Islam Ansiklopedisi, C.25, Ankara 2002, s.408-410. Tarih-Coğrafya Fakültesi Dergisi, C.6, S.5, Ankara 1948, s.431-460.

https://sozluk.gov.tr/ (E.T. 20.02.2020)

https://tr.eferrit.com/eisenhower-soyadi-anlami-ve-koekeni/ (E.T. 17.02.2020) 